\title{
Peak to post-peak thermal history of the Saglek Block of Labrador: A multiphase and multi-instrumental approach to geochronology
}

\author{
Monika A. Kusiak ${ }^{\mathrm{a}, \mathrm{b}, *}$, Daniel J. Dunkley ${ }^{\mathrm{a}, \mathrm{c}}$, Martin J. Whitehouse ${ }^{\mathrm{d}}$, Simon A. Wilde ${ }^{\mathrm{c}}$, \\ Anna Sałacińska ${ }^{a}$, Patrík Konečnýe, Krzysztof Szopa ${ }^{\mathrm{f}}$, Aleksandra Gawęda ${ }^{\mathrm{f}}$, David $\mathrm{Chew}^{\mathrm{g}}$ \\ a Institute of Geological Sciences, Polish Academy of Sciences, Twarda 51/55 St., PL-00818 Warsaw, Poland \\ ${ }^{\mathrm{b}}$ GeoForschungsZentrum Potsdam, 3.3 D-14473 Potsdam, Germany \\ c Department of Applied Geology, Curtin University, PO Box U1987, WA 6845, Perth, Australia \\ d Swedish Museum of Natural History, SE104 05 Stockholm, Sweden \\ e State Geological Institute of Dionýz Štúr, Mlynská dolina 1, 81704 Bratislava 11, Slovakia \\ ${ }^{\mathrm{f}}$ Faculty of Earth Sciences, University of Silesia ul. Będzińska 60, 41-200 Sosnowiec, Poland \\ ${ }^{g}$ Department of Geology, School of Natural Sciences, Trinity College Dublin, Dublin 2, Ireland
}

\section{A R T I C L E I N F O}

\section{Keywords:}

Labrador

$\mathrm{U}-\mathrm{Pb}$ geochronology

Monazite

Zircon

Apatite

\begin{abstract}
A B S T R A C T
The Saglek Block of coastal Labrador forms the western margin of the North Atlantic Craton, where Archean gneisses and granulites have been reworked during the Paleoproterozoic. Previous work has established that the block is a composite of Eoarchean to Mesoarchean protoliths metamorphosed to upper amphibolite and granulite facies at around 2.8-2.7 Ga. New in-situ microbeam dating of accessory minerals in granoblastic gneisses reveals a complex peak to post-peak thermal history. Zircon growth at ca. 3.7-3.6 Ga provides the age of formation of the tonalitic protoliths to the gneisses. Further zircon growth in syn-tectonic granitic gneiss and monazite growth in a variety of orthogneisses confirm peak metamorphic conditions at ca. $2.7 \mathrm{Ga}$, but also reveal high-temperature conditions at ca. $2.6 \mathrm{Ga}$ and $2.5 \mathrm{Ga}$. The former is interpreted as the waning stages of the $2.7 \mathrm{Ga}$ granulite event, whereas the latter is associated with a younger phase of granitic magmatism. In addition, apatite ages of ca. $2.2 \mathrm{Ga}$ may represent either cooling associated with the $2.5 \mathrm{Ga}$ event or a previously unrecognized greenschist-facies metamorphism event that predates the Torngat Orogeny.
\end{abstract}

\section{Introduction}

High-grade metamorphic rocks are typically produced during major episodes of orogenic activity, and not only record peak events, but also the waning stages, which often involve retrograde mineral reactions during cooling, rehydration, and deformation. Such post-peak processes are impossible to distinguish from those produced by separate, subsequent orogenic events without the information provided by mineralbased isotopic geochronology, where mineral phases specifically associated with discrete stages of metamorphism can be used to reliably date these events. This study utilizes a variety of mineral geochronometers to unravel the complex peak and post-peak history of the Archean Saglek Block of Labrador. This is important because microbeam techniques (including electron and ion microprobe analyses) have demonstrated an ability to resolve multiple stages of metamorphic activity in individual samples through careful texturally constrained insitu measurements (e.g. Montel et al., 1996; Dunkley et al., 2008; Williams et al., 2011). A suite of microbeam analytical techniques was applied to the dating of accessory monazite, zircon and apatite - as both grain separates and in polished thin sections - with a dual focus on petrographic relationships and sub-grain isotopic complexity in order to reveal the connection between mineral growth and various metamorphic processes.

\section{Geological setting}

The Saglek Block is the name given to the central part of Nain Province, which extends along the northeastern coast of the Labrador Peninsula, constituting the westernmost part of the Archean North Atlantic Craton (Fig. 1). It is bounded to the north by the Nachvak Block and to the south by the Hopedale Block. The Paleoproterozoic TransHudson Orogen $(2.0-1.8 \mathrm{Ga})$ defines the southern boundary of the Nain Province, where the Saglek Block was thrust over the Churchill Province during the 1.8-1.7 Torngat Orogeny (Ryan, 1990; Van Kranendonk, 1996), involving significant reworking of the Archean gneissic crust (Van Kranendonk and Helmstaedt, 1990). The Saglek

\footnotetext{
* Corresponding author at: Institute of Geological Sciences, Polish Academy of Sciences, Twarda 51/55 St., PL-00818 Warsaw, Poland.

E-mail address: monika.kusiak@twarda.pan.pl (M.A. Kusiak).
} 


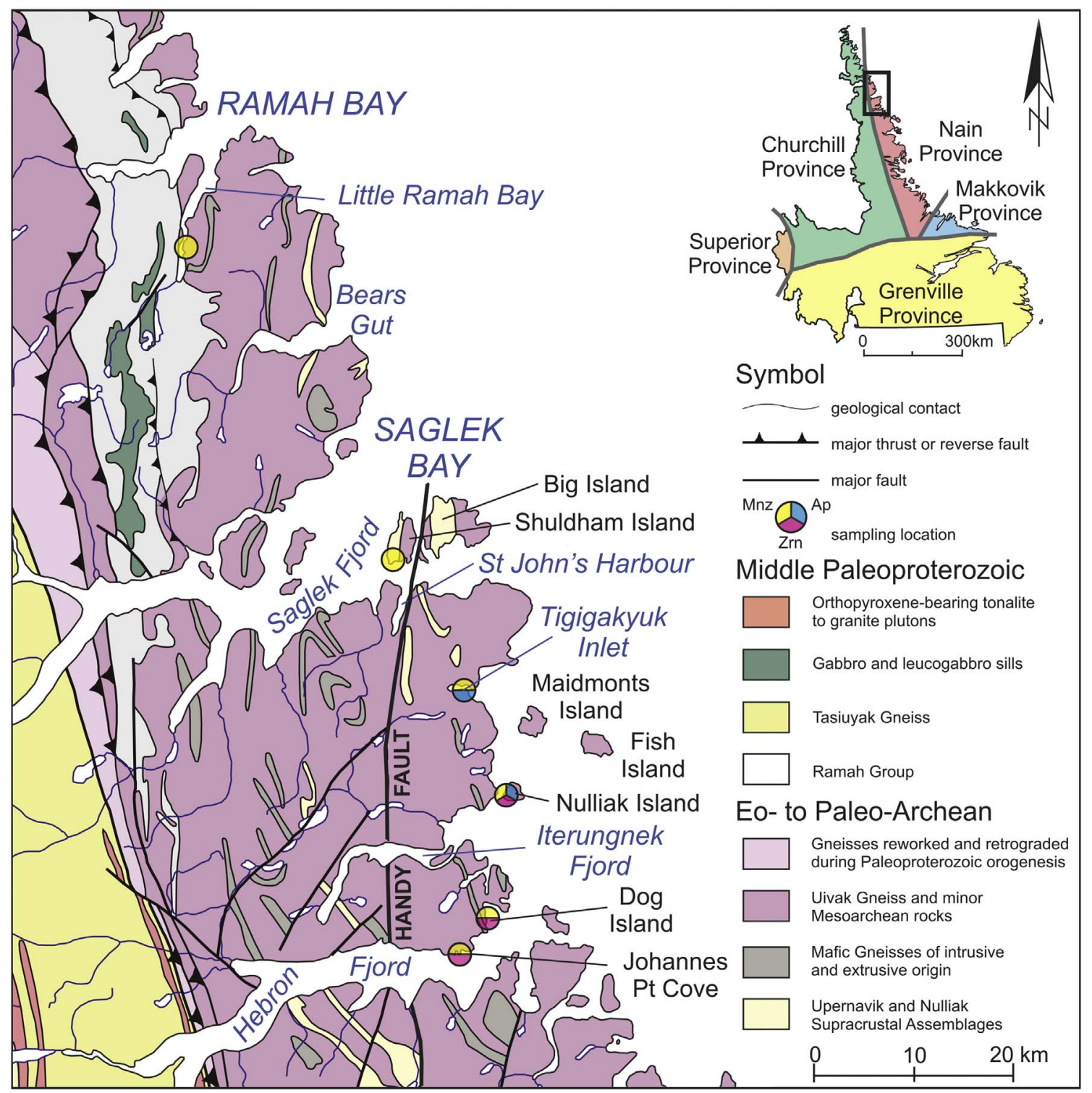

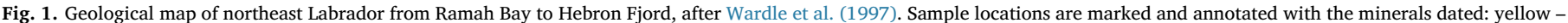
monazite, pink - zircon, blue - apatite. (For interpretation of the references to colour in this figure legend, the reader is referred to the web version of this article.)

Block is composed predominantly of quartzo-feldspathic gneisses with protolith ages between $2.7 \mathrm{Ga}$ and $3.9 \mathrm{Ga}$, which were pervasively deformed and metamorphosed at amphibolite- to granulite-facies conditions at ca. 2.8-2.7 Ga (Schiøtte et al., 1989a). The dominant component of the Saglek Block is the Uivak gneiss, which is subdivided into two types: Eoarchean ( $>3.6 \mathrm{Ga}$ ) Uivak I gneisses of tonalite-trondhjemite-granodiorite (TTG) composition, and slightly younger $(\sim 3.6 \mathrm{Ga})$ Uivak II augen gneisses, which include Fe-rich porphyritic granodiorites and diorites (Bridgwater and Schiøtte, 1991; Collerson and Bridgwater, 1979). The Uivak I gneiss is a composite of different magmatic protoliths, and contains enclaves of Fe-rich monzodiorites (Collerson et al., 1992) and tonalities (Komiya et al., 2015). These authors have suggested the enclaves were derived from $>3.9$ Ga protoliths, the 'Nanok' and 'Iqaluk' gneisses, respectively. However, these interpretations are based on dating of zircon that may be xenocrystic, and these names for older magmatic suites are not widely used. Packages of supracrustal rocks are found as macro-scale enclaves and tectonically intercalated units in both Uivak I and II; those that are intruded by deformed and metamorphosed mafic 'Saglek' dykes were classified as the Nulliak assemblage, whereas those without Saglek dykes were grouped together as the Upernavik Supracrustals (Bridgwater and Schiøtte, 1991). The
Nulliak assemblage is regarded as predating the emplacement of the Uivak I gneisses, and the Upernavik Supracrustals as post-dating them. However, relationships are often ambiguous in the field due to pervasive ductile deformation and metamorphism between 2.77 and $2.71 \mathrm{Ga}$ (Schiøtte et al., 1989a). Metamorphism was at granulite facies over most of the Saglek Block, involving widespread partial melting. An exception are the gneisses east of the Handy Fault (Fig. 1) that extend southward from the west side of Big Island in Saglek Bay, through St. John's Harbour and Hebron Fjord (Bridgwater et al., 1975), and down to Okak Island (Ermanovics et al., 1988; Ermanovics et al., 1989). The gneisses near Saglek Bay were metamorphosed to amphibolite facies, with metamorphic grade increasing to granulite facies southwards to Hebron Fjord (Bridgwater et al., 1990). This southward transition from amphibolite to granulite facies has been attributed to a scissor-like movement along the Handy Fault, with amphibolite-facies gneisses representing a higher level of exposed Archean crust (Ryan et al., 1983; Ryan et al., 1984; Schiøtte et al., 1986). Further details of the granulites, migmatites and amphibolite-facies gneisses are presented in various publications (Bridgwater and Schiøtte, 1991; Schiøtte and Bridgwater, 1990) to which the reader is referred. There is also an episode of ca. $2.5 \mathrm{Ga}$ magmatism affecting gneisses across the Saglek 
Table 1

Sample location and modal mineralogy.

\begin{tabular}{|c|c|c|c|c|c|}
\hline Sample & Location & Unit & Type & Latitude & Longitude \\
\hline L14-15 & Dog Island & Uivak I & Meta-tonalite & $58^{\circ} 11,57^{\prime}$ & $62^{\circ} 36,66^{\prime}$ \\
\hline L14-19 & Johannes Point Cove & Uivak I & Meta-tonalite & $58^{\circ} 11,56^{\prime}$ & $62^{\circ} 36,62^{\prime}$ \\
\hline L14-29 & Nulliak Island & Nulliak assemblage & Meta-granite & $58^{\circ} 18,62^{\prime}$ & $62^{\circ} 35,82^{\prime}$ \\
\hline L14-39 & Tigigakyuk Inlet & Uivak I & Meta-tonalite & $58^{\circ} 18,68^{\prime}$ & $62^{\circ} 35,77^{\prime}$ \\
\hline L14-50 & Shuldham Island & Upernavik supracrustals & Meta-pelite & $58^{\circ} 31,13^{\prime}$ & $62^{\circ} 47,90^{\prime}$ \\
\hline L14-87 & Little Ramah Bay & Uivak I & Meta-andesite & $58^{\circ} 48,04^{\prime}$ & $63^{\circ} 10,42^{\prime}$ \\
\hline
\end{tabular}

\begin{tabular}{|c|c|c|c|c|c|c|c|c|c|c|c|c|c|c|c|c|c|}
\hline Sample & Qtz & $\mathrm{Pl}$ & Afs & $\mathrm{Gt}$ & Sil & $\mathrm{Bt}$ & $\mathrm{Hb}$ & Cpx & Chl & Act & Ox & Ser & Aln & Ep & Ap & Zrn & Mnz \\
\hline L14-15 & $\cdots$ & ... & .• & & & • & & & & & & & $\mathrm{s}$ & $\mathrm{s}$ & • & • & • \\
\hline L14-19 & $\cdots$ & $\cdots$ & $\bullet$ & & & • & & & & & & $\mathrm{s}$ & $s$ & $\mathrm{~s}$ & • & • & • \\
\hline L14-29 & $\cdots$ & $\cdots$ & $\cdots$ & & & - & & & & & $\cdot s$ & $\mathrm{~s}$ & $\mathrm{~s}$ & $\mathrm{~s}$ & $\cdot$ & • & • \\
\hline L14-39 & •• & $\cdots$ & •• & & & • & & & & & -s & $\mathrm{s}$ & $s$ & $\mathrm{~s}$ & • & • & • \\
\hline L14-50 & ... & ... & ... & ... & •• & •. & & & & & • & $\mathrm{s}$ & & & • & • & • \\
\hline L14-87 & .• & $\cdots$ & • & & & - & - & •• & $\mathrm{s}$ & $\mathrm{s}$ & $\cdot s$ & $\mathrm{~s}$ & $\mathrm{~s}$ & $\mathrm{~s}$ & • & • & • \\
\hline
\end{tabular}

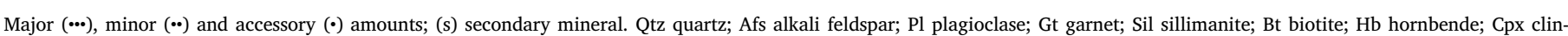
opyroxene (augite); Chl chlorite; Act actinolite; Ox Fe-Ti oxides; Ser sericite; Aln allanite; Ep epidote; Ap apatite; Zrn zircon; Mnz monazite.

Block, with the emplacement of abundant granitoid dykes and stocks (Baadsgaard and Collerson, 1979). Overall, the gneisses of the Saglek Block were retrogressed to varying degrees by Paleoproterozoic events, especially towards the Churchill Province in the west. More details on the geological setting are provided in Kusiak and Sałacińska (2016) and Sałacińska and Kusiak (2017).

As part of a broader study of the Archean Saglek Block, we selected a suite of samples containing monazite and apatite as well as zircon, to place further constrains on the late Archean to Paleoproterozoic history.

\section{Samples}

Six samples were selected for this study from localities along an $80 \mathrm{~km}$ stretch of coast between Hebron Fjord and Little Ramah Bay (Fig. 1). Sample locations, rock-types and mineral assemblages are given in Table 1.

Sample L1419 from Johannes Point Cove is fine-grained, pale, grey meta-tonalite typical of the Uivak I gneiss. It consists of granoblastic quartz and plagioclase with minor K-feldspar and biotite. Accessory monazite, zircon and apatite are present. Plagioclase is partially altered to sericite, and biotite is altered to chlorite, titanite and/or sagenitic rutile. Monazite occurs either as well formed grains with triple point boundaries, indicating growth simultaneous with the adjacent minerals (Fig. 2a), or as inclusions in quartz (Fig. 2b). Monazite grain boundaries (Fig. 3a) are commonly corroded, with apatite-allanite-epidote breakdown coronas (Fig. 3b), as first described in the Tauern Window of the Granatspitz massif in the central eastern Alps (Finger et al., 1998). In detail, corroded monazite is surrounded by apatite, which in turn is surrounded by allanite that grades outwards into epidote. Zircon occurs as either elongate grains with rounded terminations, or as ovoid grains with well-developed bright-CL overgrowths (Fig. 4a, b). A magmatic origin is attributed to the cores, whereas the rims are typical of zircon growth during high-grade metamorphism (Vavra et al., 1996).

Sample L1415 is a Uivak I grey tonalitic orthogneiss from Dog Island. It is fine-grained, with a strong gneissosity defined by biotiterich bands and discontinuous laminations of coarser K-feldspar, plagioclase and quartz, indicating partial melting before and/or during deformation. It contains accessory monazite, zircon and apatite. Secondary alteration of biotite to chlorite, titanite and $\mathrm{Fe}$ oxide, and sericitisation of plagioclase, is pervasive. Monazite commonly has coronas of apatite, allanite and epidote, similar to sample L1419 (Fig. 3d). The original margins of the monazite are now marked by the boundary between allanite and epidote. There are two types of biotite breakdown reactions: 1) symplectite biotite + plagioclase $=$ chlorite + albite $+\mathrm{Ca}$, and 2) biotite pseudomorphed by chlorite $+\mathrm{Fe}$-Ti oxides. The biotite breakdown and monazite breakdown both involve hydration but may not be coeval. For monazite breakdown, REE mobility is limited producing gradation from allanite to epidote. Calcium for apatite most likely came from plagioclase. Zircon grains are mainly elongate with rounded terminations (Fig. 4b, c). Cathodoluminescence imaging reveals prismatic cores with dipyramidal terminations, which are interpreted as growth during magmatic crystallization of the tonalitic protolith. All grains have rounded overgrowths of relatively bright-CL (Fig. 4c, d), typical of zircon growth or recrystallization during highgrade metamorphism.

Sample L1429 from SW Nulliak Island is a fine-grained metagranite, which crops out in metre- to tens of metre-thick layers within the Nulliak supracrustal assemblage. The sample lacks the strong gneissosity of the Uivak I gneiss, but contains a foliation defined by aligned biotite and flattened quartz, plagioclase and microcline grains, consistent with dynamic recrystallization under high-strain granulitefacies conditions. Magnetite, monazite, zircon and apatite occur as accessory minerals, commonly in association with each other (Fig. 3g). Myrmekite replaces plagioclase at some grain boundaries with microcline. Biotite alteration to chlorite and sagenitic rutile is common, as is monazite breakdown to allanite and apatite (Fig. 3g). Alteration is mostly restricted to grain boundaries, indicating hydration along intergranular pathways during a later event. Zircons in this sample are anhedral, with short prisms and well-developed dipyramidal terminations (Fig. 4e, f). Unlike zircon from the samples described above, overgrowths are extremely thin to absent.

Sample L1439 from the southern entrance of Tigigakyuk Inlet is a pale grey tonalitic orthogneiss. It is fine-grained and lacks gneissosity, but has a weak foliation defined by biotite. The location has been mapped as Uivak II gneiss, however, the sample and surrounding gneisses lack the biotite-rich and porphyroblastic characteristics of that gneiss, and so it is here classified as Uivak I. It consists mainly of plagioclase and quartz, with minor microcline and biotite, and accessory monazite, zircon and apatite, together with Fe-Ti oxides. Microcline is commonly perthitic and myrmekite is common at plagioclase contacts. Biotite alteration to chlorite and sagenitic rutile is widespread. Where enclosed within quartz grains, monazite is unaltered, with polygonal or rounded edges indicating growth in equilibrium with the granoblastic fabric of the gneiss (Fig. 2b). Monazite grains occurring along grain boundaries are commonly altered, with coronas of apatite and allaniteepidote intergrown with seriticised plagioclase (Fig. 3i).

Sample L1450 from Shuldham Island is a pelitic gneiss from the 

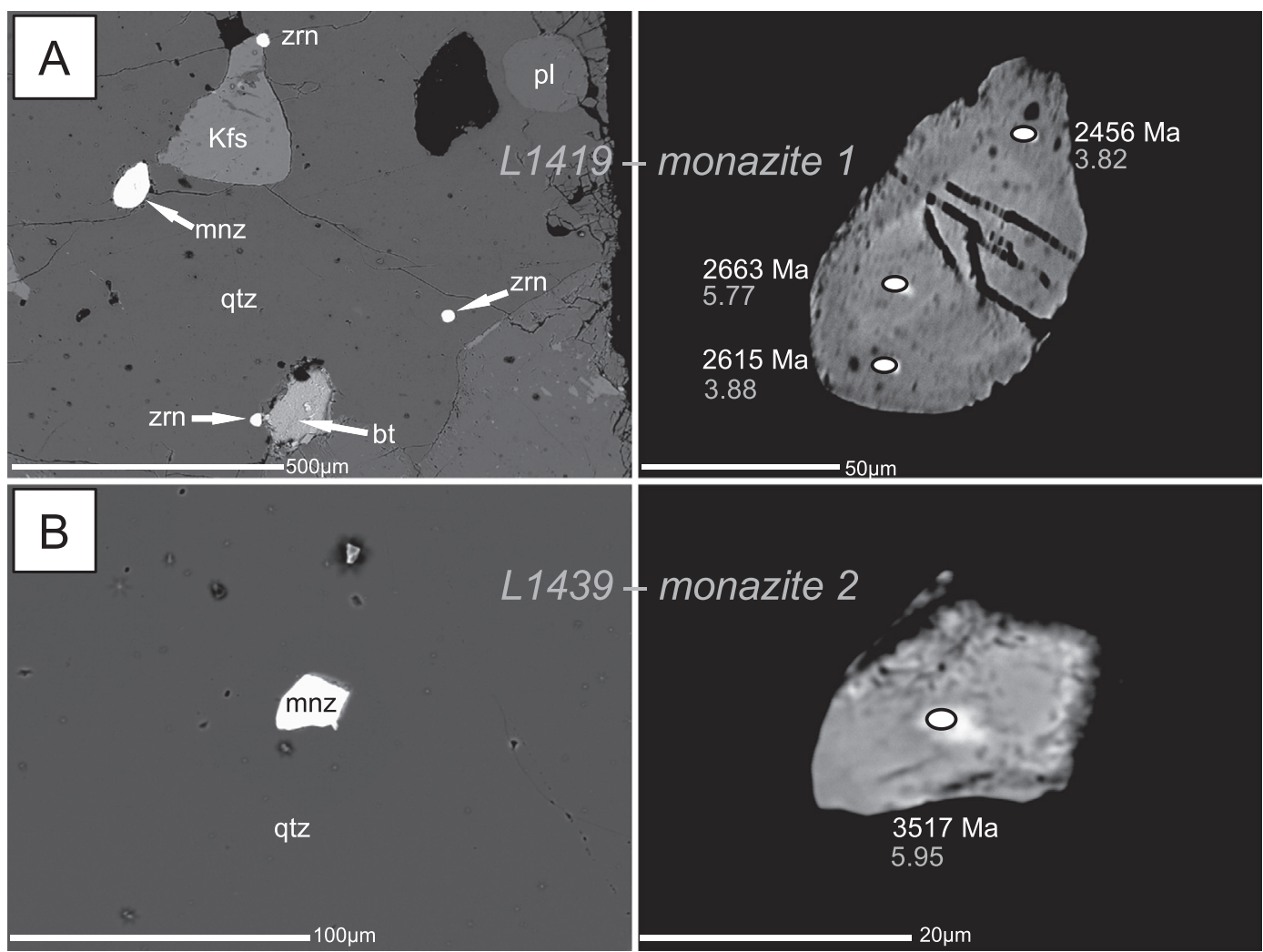

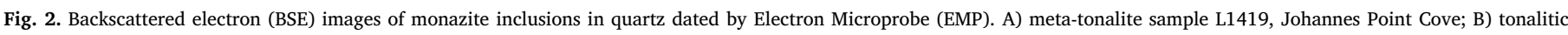

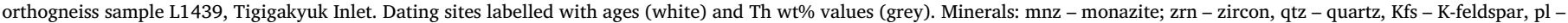
plagioclase, bt - biotite.

Upernavik Supracrustals. It is fine-grained, with garnet up to a few millimetres in diameter set in a strongly foliated assemblage of quartz, K-feldspar, plagioclase and biotite, with minor sillimanite and accessory pyrite, magnetite, apatite, monazite, and zircon. Secondary alteration is pervasive, similar to previous samples. Monazite in this sample is anhedral with polygonal margins, texturally equilibrated with the granoblastic fabric.

Sample L1487 from Little Ramah Bay is an intermediate orthogneiss. It is fine-grained, greenish-grey, with flattened clusters containing intergrowths of hornblende, biotite and plagioclase indicating recrystallization of a porphyritic rock during high-grade metamorphism. The matrix contains a granoblastic assemblage of plagioclase, quartz, and augite with minor amounts of biotite, hornblende and Fe-Ti oxides. Hydrous retrogression of the granoblastic assemblage is pervasive, with most of the clinopyroxene replaced by chlorite, tremolite and epidote, the biotite by chlorite and Fe-Ti oxides, and the plagioclase by sericite. Accessory minerals include apatite and pyrite, with lesser amounts of monazite and zircon. In almost all cases, monazite is surrounded by well-developed coronas of apatite, allanite and epidote. Although the locality has been mapped as Uivak gneiss, the composition is uncharacteristic. The presence of recrystallized hornblende-rich porphyroblasts, the overall mineralogy and the abundance of sulphides and phosphates is more consistent with a meta-volcanic origin, specifically a meta-andesite.

\section{Methodology}

Thin sections from all samples were prepared and examined using an optical microscope and utilizing an Electron MicroProbe (EMP). Zircon, apatite and monazite grains were separated from crushed samples and mounted in epoxy discs with standard reference materials (91500 zircon, McClure Mountain, Madagascar and Durango apatite, and Thompson Mine and 44069 monazite), then polished to expose the mid-sections of grains. The mounts were cleaned, gold coated for analysis by SIMS (Secondary Ion Mass Spectrometry), then re-cleaned and carbon coated for EMP analysis. In addition, monazite was analysed in polished thin sections. All grains were imaged for internal structure using a scanning electron microscope fitted with backscattered electron (BSE) and cathodoluminescence (CL) detectors.

\subsection{Monazite}

Electron microprobe analyses were performed at the Electron Microprobe Laboratory, State Geological Institute of Dionýza Štúra in Bratislava, Slovakia, utilizing a Cameca SX-100 electron microprobe equipped with four wavelength-dispersive spectrometers. Large highsensitivity, LPET and LLIF crystals and a conventional TAP crystal were used for analysis. An accelerating voltage of $15 \mathrm{kV}$ was used, with a probe current of $200 \mathrm{nA}$. The X-ray line measured, standard used, counting time and detection limit for each element are presented in Table S1. Difficulties introduced by line interferences among REE, Th, $\mathrm{Pb}$ and $\mathrm{U}$ were dealt with, in the case of strong peak overlaps, by choosing alternative, normally lower intensity lines. Remaining interferences were resolved by empirically measured correction factors (Åmli and Griffin, 1975). $\mathrm{Pb} M_{\alpha}$ were preferred over $\mathrm{Pb} M_{\beta}$ due to higher intensity and resolvable interferences. To obtain correct $\mathrm{Pb}$ estimates, a critical interference of $\mathrm{YL}_{\gamma 2,3}$ on $\mathrm{PbM}_{\alpha}$ has to be corrected. An interference at the $\mathrm{Pb} M_{\alpha}$ position results from the combined effect of $\mathrm{Th} M_{\zeta 1}$ and $\mathrm{Th} M_{\zeta 2}$ lines. This interference is relevant in the case of high Th monazites. $\mathrm{U}$ measured on $\mathrm{UM}_{\beta}$ is also affected by interference with the Th lines $\mathrm{Th} M_{\gamma}$, ThM5-P3 and $\mathrm{Th} M 4 \mathrm{O}_{2}$. Moreover, the background postion at the higher wavelength side is affected by the presence of a Th-M5 absorption edge. Consequently, background intensity was measured on the lower wavelength side of the $\mathrm{UM}_{\beta}$ and a slope factor 0.888 was used to extrapolate the background at the line position. At the start 

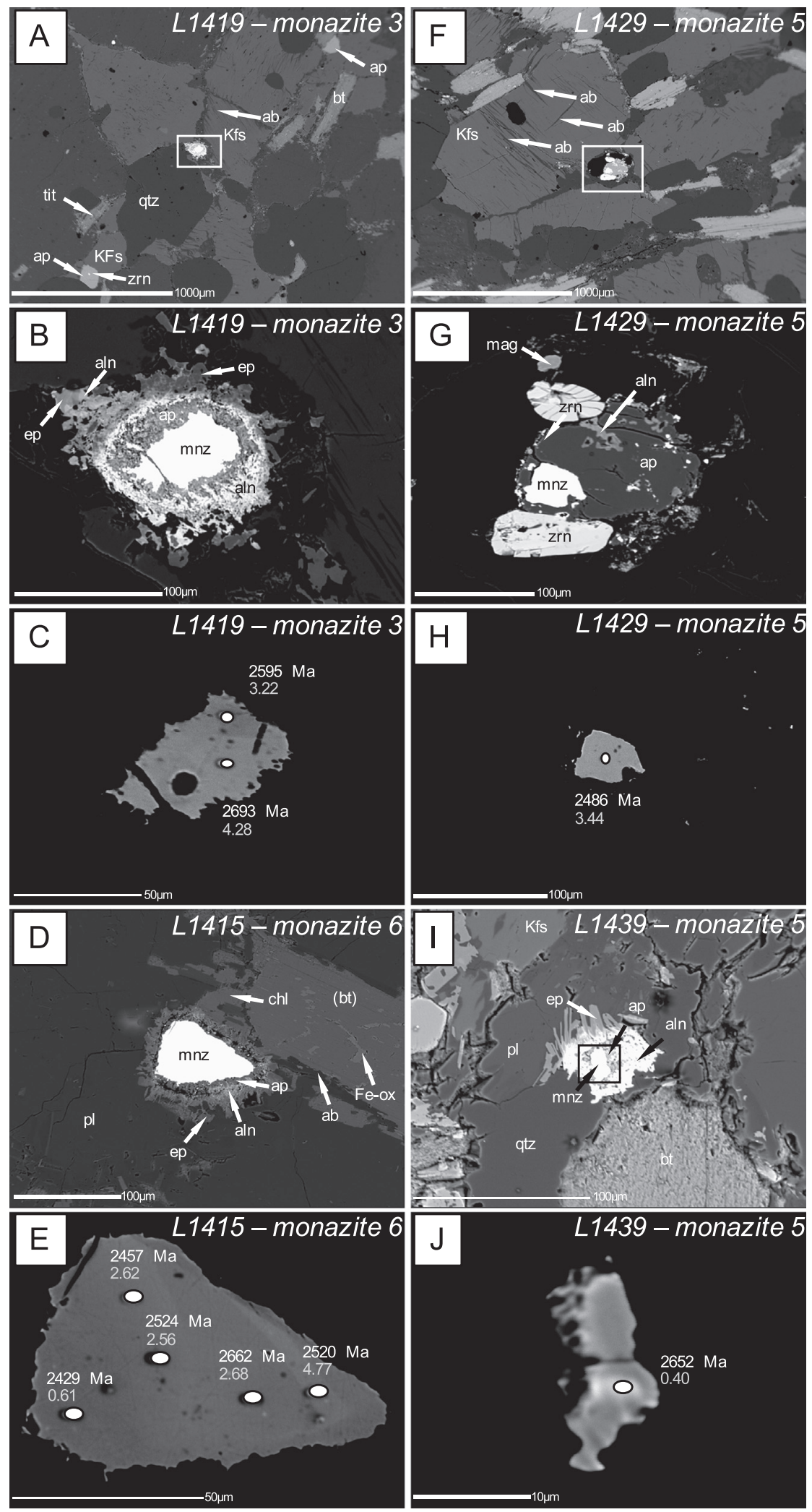

Fig. 3. BSE images of monazite along grain boundaries, with retrograde coronas of allanite, apatite and epidote. A, B, C) sample L1419, Johannes Point Cove; D, E) sample L1415, Dog Island; F, G, H) sample L1429, Nulliak Island; I, J) sample L1439, Tigigakyuk Inlet. Minerals: mnz - monazite, zrn - zircon, qtz - quartz, Kfs - Kfeldspar, pl - plagioclase, bt - biotite, (bt) - biotite altered to chlorite + Fe-Ti-oxide; ap - apatite, ep - epidote, aln - allanite, tit titanite, ab - albite, chl - chlorite. of each dating session, a set of monazite reference materials were analysed: Thompson Mine with radiogenic ${ }^{206} \mathrm{~Pb} /{ }^{238} \mathrm{U}=0.3153$ and $\mathrm{U}=\sim 2100$ ppm, for U-Th content; and 44069 (424.9 Ma) for age calibration, dated by TIMS (Thermal Ionisation Mass Spectrometry) and also by SHRIMP (Sensitive High Resolution Ion Microprobe; Aleinikoff et al., 2006). These were used to test the effectiveness of correction factors, with the weighted mean of apparent ages from analyses accepted when within 5 m.y. of the published age of each standard. Analytical spot positions on sample grains were carefully selected using high-contrast BSE images and X-ray element maps. Data reduction and calculation of $\mathrm{Th} * \mathrm{~Pb}$ ages (where $\mathrm{Th}^{*}$ equals $\mathrm{Th}$ plus $\mathrm{U}$ recalculated to equivalent Th) were undertaken using the DAMON software (Konečný 


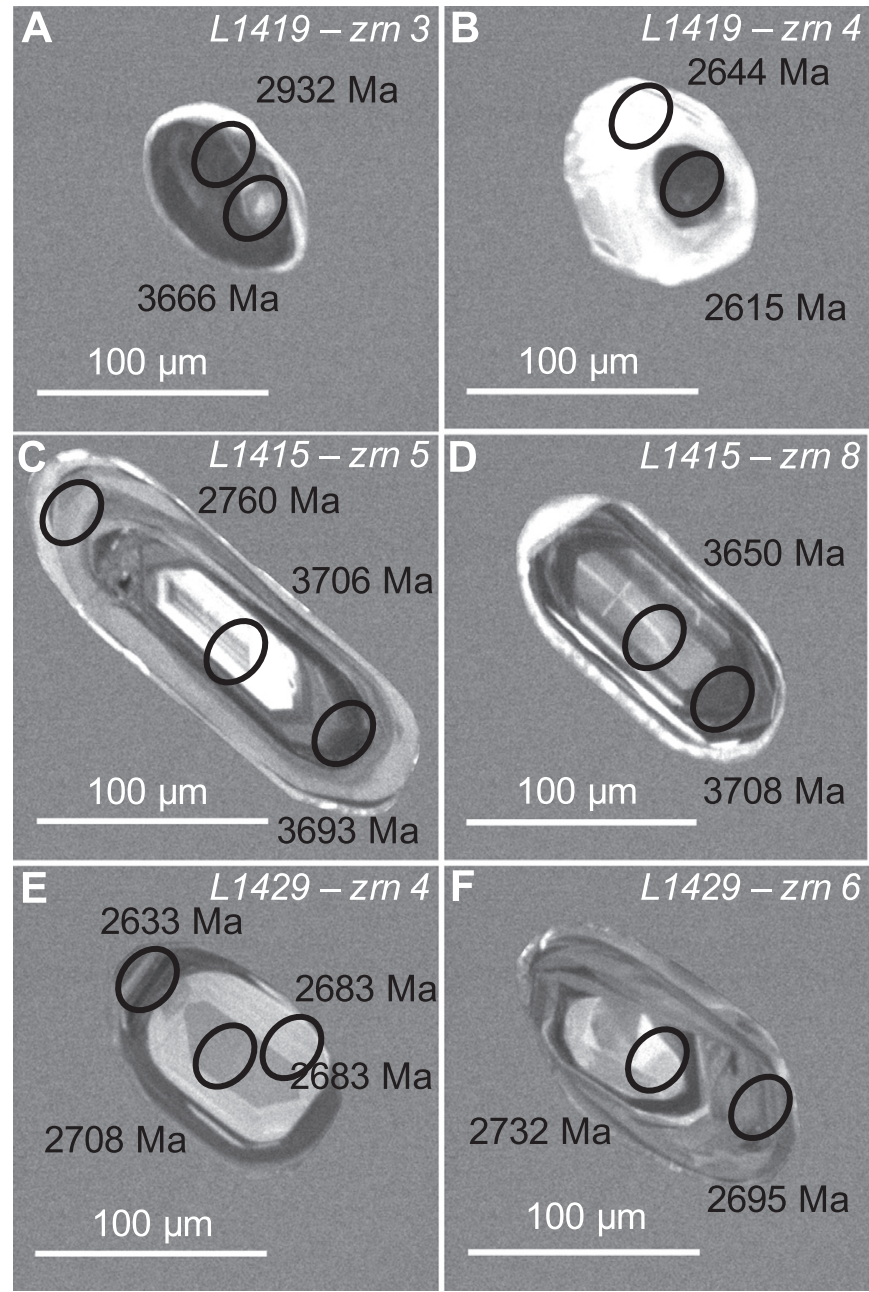

Fig. 4. Cathodoluminescence (CL) images of zircon showing analytical sites. A, B) sample L1419, Johannes Point Cove; C,D) sample L1415, Dog Island; E,F) sample L1429 from Nulliak Island; zircon spot numbers and ages correspond to the grain analyses in the supplementary data tables (Tables S3, S5, S7)

et al., 2004). This software calculates dates following the methodology of Montel et al. (1996). The analytical routine has previously been successfully applied for dating monazite (Hogdahl et al., 2012; Majka et al., 2012; Konečný et al., 2017). Pooled ages, construction of histograms and probability density curves were calculated by Isoplot 3.50.

In order to provide a comparison with EMP age estimates, monazite grains from sample L1450 were also analysed by SHRIMP II at the John de Laeter Centre, Curtin University in Perth, Western Australia. A 0.3-0.5 nA primary $\mathrm{O}_{2}{ }^{-}$ion beam was used to produce a $10 \mu \mathrm{m}$ wide spot on the sample surface. Secondary ionisation was measured without energy filtering on a single electron multiplier for 13 mass stations, from $202\left(\mathrm{LaPO}_{2}\right)$ to $270\left(\mathrm{UO}_{2}\right)$, with a mass resolution of $>5500$ for 270. Secondary ion retardation was used to eliminate ion scatter. Mass stations $202\left(\mathrm{LaPO}_{2}\right), 203\left(\mathrm{CePO}_{2}\right), 205.9\left(\mathrm{NdPO}_{2}\right), 232(\mathrm{Th}), 244.8$ $(\mathrm{YCeO})$ and $264\left(\mathrm{ThO}_{2}\right)$ were analysed for matrix corrections and interference on ${ }^{204} \mathrm{~Pb}$, following the protocols outlined in Fletcher et al. (2010). Mass stations were measured through 6 cycles, with typical count times of 10 s per cycle for ${ }^{204} \mathrm{~Pb}$, background (at $204.04 \mathrm{amu}$ ) and ${ }^{206} \mathrm{~Pb}$, 30s for ${ }^{207} \mathrm{~Pb}$ and $5 \mathrm{~s}$ for ${ }^{208} \mathrm{~Pb}$. Reduction of raw data for standards and samples was performed using the SQUID 2.5 and Isoplot 3.7 add-ins for Microsoft Excel 2003 (Ludwig, 2001, 2009). Age $\left({ }^{206} \mathrm{~Pb} /{ }^{238} \mathrm{U}\right)$ and abundance of $\mathrm{U}$ were calibrated against reference monazite French (514 Ma; 1000 ppm U). High La and high Y-Nd-U standards GSC2234 and GSC2908, respectively, were used for matrix and interference corrections (Fletcher et al., 2010). Corrections for common $\mathrm{Pb}$ on isotopic $\mathrm{U}-\mathrm{Pb}$ values and ages were calculated with common $\mathrm{Pb}$ estimated from ${ }^{204} \mathrm{~Pb}$ counts and the Stacey and Kramers (1975) common $\mathrm{Pb}$ model for Broken Hill lead.

\subsection{Zircon}

Zircon grains in samples L1415, L1419 and L1429 were analysed with the CAMECA IMS 1280 ion microprobe at the NordSIMS facility, Swedish Museum of Natural History in Stockholm. Isotopic analysis for $\mathrm{U}-\mathrm{Pb}$ closely followed the published methodology (Whitehouse and Kamber, 2005). Zircon grains were analysed using a ca. $15 \mu \mathrm{m}, 6 \mathrm{nA} \mathrm{O}{ }_{2}^{-}$ primary beam, and peak-hopping monocollection by an ion counting electron multiplier (EM) at a mass resolution of ca. $5400(\mathrm{M} / \Delta \mathrm{M})$. Standard zircon 91500 was used for calibration of $\mathrm{Pb} / \mathrm{U}$ ratios using the $\mathrm{Pb} / \mathrm{UO}$ vs. $\mathrm{UO}_{2} / \mathrm{UO}$ calibration protocol of Jeon and Whitehouse (2015) with $\mathrm{U}$ concentration of $80 \mathrm{ppm}$, and age of $1065 \mathrm{Ma}$ (Wiedenbeck, 1995). Common $\mathrm{Pb}$ was corrected using the ${ }^{204} \mathrm{~Pb}$ counts assuming a present-day terrestrial Pb-isotope composition model (Stacey and Kramers, 1975) following the rationale of Zeck and Whitehouse (1999) that this is largely surface contamination introduced during sample preparation and not common $\mathrm{Pb}$ residing in zircon and/or micro-inclusions. Very low amounts of common $\mathrm{Pb}$ were detected during the spot analyses with $f^{206} \mathrm{~Pb}<0.1 \%$, in many cases below the detection limit for ${ }^{204} \mathrm{~Pb}$ based on the electron multiplier background. Where common $\mathrm{Pb}$ corrections were deemed necessary on the basis of measurable ${ }^{204} \mathrm{~Pb}$ ( $>3 \times$ average background), these were small and therefore insensitive to the precise composition of common $\mathrm{Pb}$. Data reduction was performed using the NordSIMS-developed suite of software of M.J. Whitehouse. All ion microprobe data in the tables are quoted with $1 \sigma$ analytical uncertainties, whereas weighted mean and discordia intercept ages are quoted at 95\% confidence levels, and include the decay-constant error of the concordia curve.

\subsection{Apatite}

The fluorapatite crystals were imaged by scanning electron microscopy on a FET Philips 30 electron microscope ( $15 \mathrm{kV}$ and $1 \mathrm{nA})$ at the Faculty of Earth Sciences, University of Silesia, Sosnowiec, Poland. Apatite U-Pb data were acquired using a Photon Machines Analyte Exite $193 \mathrm{~nm}$ ArF Excimer laser-ablation system coupled to a Thermo Scientific iCAP Qc at the Department of Geology Trinity College Dublin. Twenty-seven isotopes $\left({ }^{31} \mathrm{P},{ }^{35} \mathrm{Cl},{ }^{43} \mathrm{Ca},{ }^{55} \mathrm{Mn},{ }^{86} \mathrm{Sr},{ }^{89} \mathrm{Y},{ }^{139} \mathrm{La},{ }^{140} \mathrm{Ce}\right.$, ${ }^{141} \mathrm{Pr},{ }^{146} \mathrm{Nd},{ }^{147} \mathrm{Sm},{ }^{153} \mathrm{Eu},{ }^{157} \mathrm{Gd},{ }^{159} \mathrm{~Tb},{ }^{163} \mathrm{Dy},{ }^{165} \mathrm{Ho},{ }^{166} \mathrm{Er},{ }^{169} \mathrm{Tm}$, ${ }^{172} \mathrm{Yb},{ }^{175} \mathrm{Lu},{ }^{200} \mathrm{Hg},{ }^{204} \mathrm{~Pb},{ }^{206} \mathrm{~Pb},{ }^{207} \mathrm{~Pb},{ }^{208} \mathrm{~Pb},{ }^{232} \mathrm{Th},{ }^{238} \mathrm{U}$ ) and mass ${ }^{248}\left({ }^{232} \mathrm{Th}^{16} \mathrm{O}\right)$ were acquired using a $50 \mu \mathrm{m}$ laser spot, a $4 \mathrm{~Hz}$ laser repetition rate and a fluence of $3.31 \mathrm{~J} / \mathrm{cm}^{2}$. Apatite standard Madagascar (473.5 $\pm 0.7 \mathrm{Ma}$; Cochrane et al., 2014) was used as the primary apatite reference material in this study, while McClure Mountain apatite ( $\sim 23 \mathrm{ppm}$ of $\mathrm{U}$ and $71 \mathrm{ppm}$ of Th; Chew and Donelick, 2012) was used as a secondary standard. The thermal history, crystallization age of $523.5 \pm 2.1 \mathrm{Ma}\left({ }^{207} \mathrm{~Pb} /{ }^{235} \mathrm{U}\right)$ and initial $\mathrm{Pb}$ isotopic composition $\left({ }^{206} \mathrm{~Pb} /{ }^{204} \mathrm{~Pb}=17.54 \pm 0.04\right)$ of the latter are known from TIMS analyses (Schoene and Bowring, 2006). NIST 612 standard glass was used as the apatite trace element concentration reference material. The raw isotope data were reduced using the "Vizual Age" data reduction scheme (Petrus and Kamber, 2012) in the freeware IOLITE package (Paton et al., 2011). Sample-standard bracketing was applied after the correction of down-hole fractionation to account for long-term drift in isotopic or elemental ratios by normalizing all ratios to those of the U$\mathrm{Pb}$ reference standards. Common $\mathrm{Pb}$ in the primary apatite standard was corrected using the ${ }^{207} \mathrm{~Pb}$-based correction method using a modified version of the "Vizual Age" DRS (Chew et al., 2014). The regression line was anchored to a lower intercept using a ${ }^{207} \mathrm{~Pb} /{ }^{206} \mathrm{~Pb}$ value of 0.88198, derived from an apatite ID-TIMS total U-Pb isochron (Schoene and Bowring, 2006). REE contents were normalized to C1 chondrite (Sun and McDonough, 1995) using NIST 612 glass as a primary 

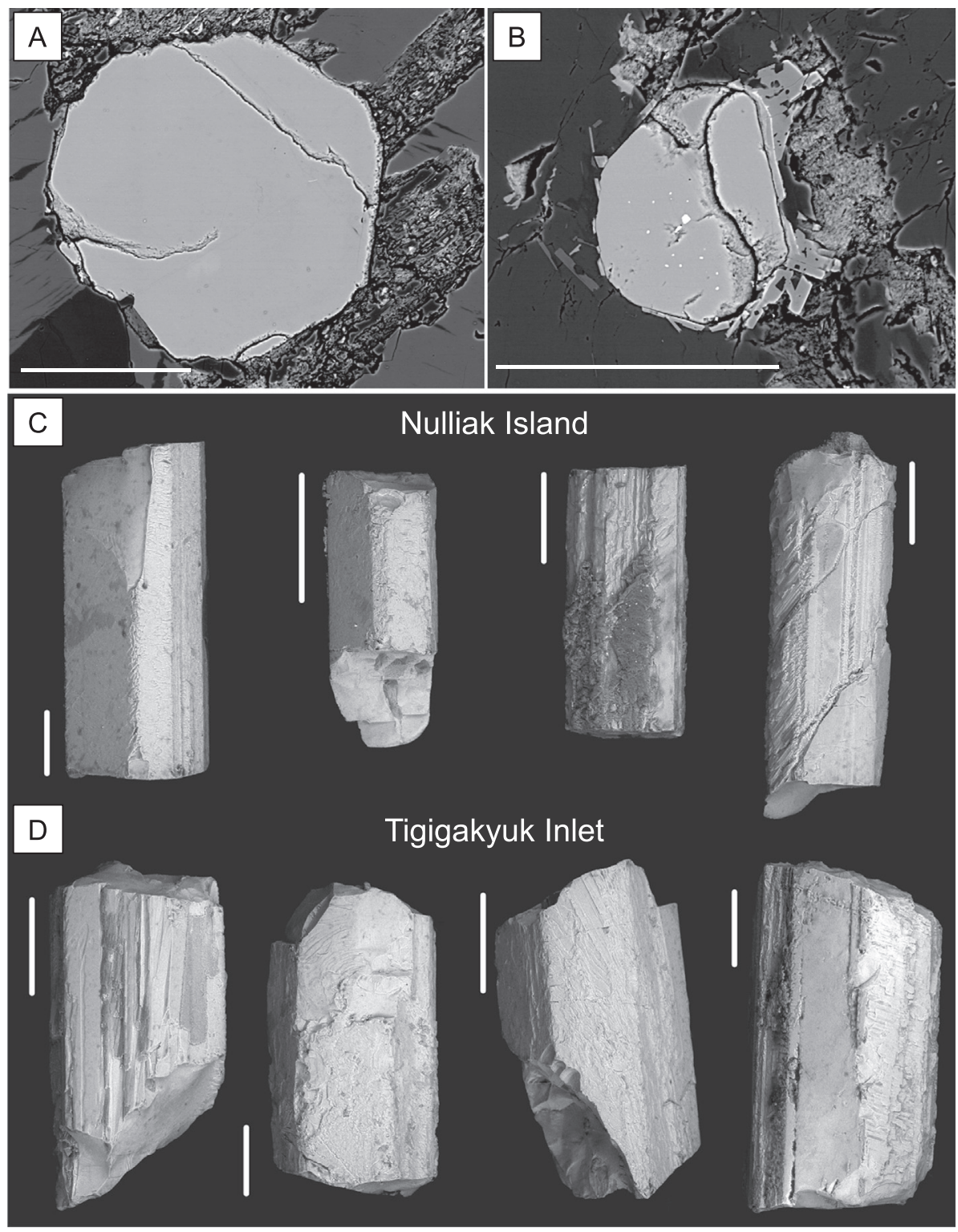

Fig. 5. BSE images of apatite crystals. A, C) sample L1429, Nulliak Island; B, D) sample L1439, Tigigakyuk Inlet. Bright inclusions in apatite are monazite and zircon. A, B) apatite grains in thin section; C, D) separated apatite grains selected for dating by laser ablation - inductively coupled plasma mass spectrometry (LA-ICPMS). All scale bars are $100 \mu \mathrm{m}$. reference material, and an aliquot of a crushed crystal of Durango apatite (Chew et al., 2016) as a secondary standard.

\section{Results}

All results are presented in Supplementary Tables S2-S13. All mean, deconvolved and concordia intercept ages in the figures, tables and text below are quoted at $95 \%$ confidence levels.

As described above, most monazite grains in thin section are anhedral, with polygonal shapes in textural equilibrium with granoblastic fabrics. Internal variations in composition are only rarely visible in BSE images (e.g. Fig. 3c, e). Thorium contents vary significantly between monazite grains, but no systematic correlation between Th content and age was observed in any of the samples.

Apatite grains in thin section are subhedral and elongate, often with prismatic forms with etched or corroded faces (Fig. 5). Generally, separated grains from sample L1429 are more prismatic than those from sample L1439. A few grains from all specimens contain tiny inclusions of monazite (Fig. 5). For geochronology and REE analysis, clear, inclusion-free grains were selected.

\subsection{Sample L1419, Johannes Point Cove}

Twenty-four monazite grains were analysed by EMP. Excluding 3 young outliers of $2092 \mathrm{Ma}, 2134 \mathrm{Ma}$ and $2335 \mathrm{Ma}$, 30 data from 24 grains form a continuous array between $2906 \mathrm{Ma}$ and $2422 \mathrm{Ma}$ (Table S2). Monazite grains both within quartz (Fig. 2a) and with breakdown coronas (Fig. 3c) contained younger and older domains, although no correlation of age with composition was found (Supplementary Fig. 1). Statistical deconvolution (with the 'Unmix Ages' function of Isoplot 4.15) yields two populations at $2660 \pm 18 \mathrm{Ma}$ and at $2455 \pm 56 \mathrm{Ma}$ (relative misfit $=0.906$; Fig. 6a). The oldest subset of data that can be considered as statistically equivalent yields a mean age of $2660 \pm 22 \mathrm{Ma}$ (MSWD $=1.4, n=28$ ), whereas the youngest subset yields a mean age of $2515 \pm 41 \mathrm{Ma}(\mathrm{MSWD}=1.9, n=7)$.

Excluding data with $>1 \%$ common $\mathrm{Pb}, 16$ SIMS data from 6 zircon grains were scattered between 3.7 and $2.7 \mathrm{Ga}$. Using a lower intercept age of $2720 \pm 50 \mathrm{Ma}$ (the approximate age of metamorphism from published zircon data), 8 data points lie along a Model 1 discordia defining an upper intercept age of $3635 \pm 42 \mathrm{Ma}(\mathrm{MSWD}=1.1$; Fig. 7a, Table S3). However, the most concordant data from zircon cores are significantly younger than the upper intercept age, with $\mathrm{Pb}-\mathrm{Pb}$ ages scattered between 3554 and 3490 Ma. 

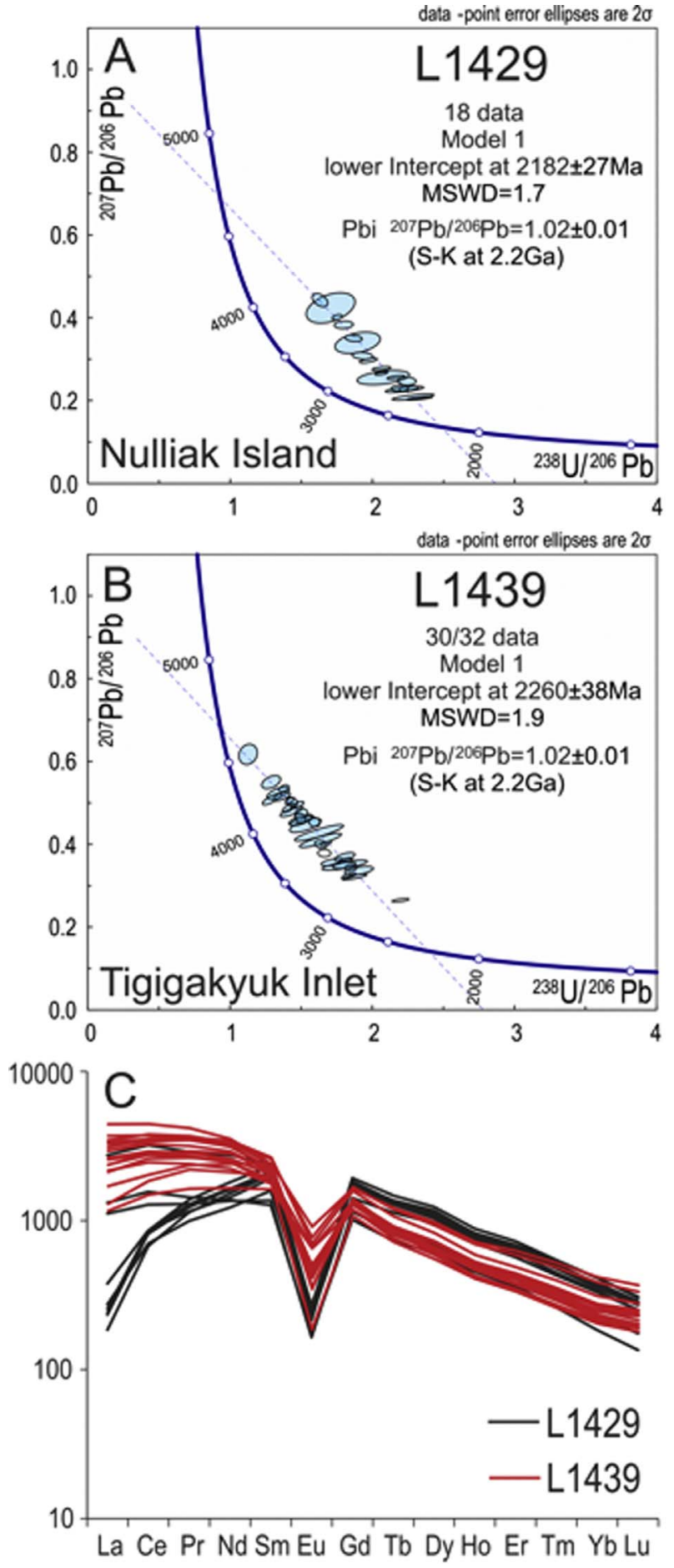

Fig. 8. Apatite analyses. (A, B) Tera-Wasserburg concordia diagrams of LA-ICPMS dating. A) sample L1429, Nulliak Island; B) sample L1439, Tigigakyuk Inlet. C) Chondrite (C1) normalized spider diagram of rare earth elements (REE) in apatite from sample L1429 (black) and sample L1439 (red). (For interpretation of the references to colour in this figure legend, the reader is referred to the web version of this article.)

\subsection{Sample L1415, Dog Island}

Twenty-five monazite grains were analysed by EMP. Excluding one outlier with an apparent age of $2254 \mathrm{Ma}, 46$ data points form a continuous array of apparent ages between $2788 \mathrm{Ma}$ and $2429 \mathrm{Ma}$ (Table S4). Some grains contain distinct domains with different apparent ages (Fig. 3e). Applying statistical deconvolution to the array yields two Gaussian populations at $2625 \pm 22 \mathrm{Ma}$ and $2519 \pm 23$ Ma (relative misfit $=0.942$; Fig. $6 \mathrm{~b}$ ). The oldest subset has a mean age of $2615 \pm 19$ Ma (MSWD $=1.4, n=29$ ), whereas the youngest subset that can be considered as statistically equivalent (with a probability of equivalence $p>0.05$ ) has a mean age of $2540 \pm 18 \mathrm{Ma}$ $(\mathrm{MSWD}=1.4, n=30)$.

Zircon analysis by SIMS yielded 18 data points from 9 grains, 12 of which lie along a Model 1 discordia (Fig. 7b, Table S5) that is fixed through the same lower intercept age of $2720 \pm 50 \mathrm{Ma}$ and record an upper intercept age of $3725 \pm 33 \mathrm{Ma}(\mathrm{MSWD}=1.5)$. Four outliers scatter along concordia between $3621 \mathrm{Ma}$ and $3437 \mathrm{Ma}$.

\subsection{Sample L1429, Nulliak Island}

Twenty-nine monazite grains were analysed by EMP. All data yield a mean age of $2462 \pm 14 \mathrm{Ma}$ (MSWD = 1.5; Fig. 6c, Table S6). Five zircon grains were analysed by SIMS, with 5 data points yielding a mean ${ }^{207} \mathrm{~Pb} /{ }^{206} \mathrm{~Pb}$ age of $2710 \pm 14 \mathrm{Ma}(\mathrm{MSWD}=2.2$; Fig. $7 \mathrm{c}$, Table S7). Eighteen apatite grains were also analysed and the data points are highly discordant due to high proportions of common $\mathrm{Pb}$ relative to radiogenic $\mathrm{Pb}$. Assuming a common $\mathrm{Pb}$ composition derived from the Stacey and Kramers (1975) two-stage model at $2.2 \mathrm{Ga}$ $\left({ }^{207} \mathrm{~Pb} /{ }^{206} \mathrm{~Pb}=1.02 \pm 0.1 \mathrm{Ma}\right)$, all data lie on a Tera-Wasserburg discordia with a lower intercept age of $2182 \pm 27$ Ma $($ MSWD = 1.7; Table S8, Fig. 8a). Apatite crystals show weak REE fractionation $\left(\mathrm{Ce}_{\mathrm{N}} /\right.$ $\mathrm{Yb}_{\mathrm{N}}=1.82-9.49$; mean value of 3.84), strong negative Eu anomalies $\left(\mathrm{Eu} / \mathrm{Eu}^{*}=0.10-0.15\right.$; mean value of 0.13$)$ and positive Ce anomalies (Ce/Ce* = 1.07-1.52; mean value of 1.34; Table S9). The REE patterns of apatite grains from this sample exhibit significant depletion in LREE (Fig. 8c).

\subsection{Sample L1439, Tigigakyuk Inlet}

Thirteen monazite grains were analysed by EMP. Excluding one older outlier of $3517 \mathrm{Ma}$, which came from an inclusion in quartz (Fig. 2b), 15 analyses form a continuous array between $2767 \mathrm{Ma}$ and 2417 Ma (Table S10). Statistical deconvolution yields two Gaussian populations at $2694 \pm 28 \mathrm{Ma}$ and $2461 \pm 32 \mathrm{Ma}$ (relative misfit $=0.628$; Fig. $6 \mathrm{~d}$ ). The oldest subset yields a mean age of $2718 \pm 33 \mathrm{Ma}$ (MSWD $=2.3, n=5$ ), whereas the youngest subset that can be considered as statistically equivalent yields a mean age of $2463 \pm 31 \mathrm{Ma}$ (MSWD $=0.5, n=9$ ). These mean ages do not overlap, and correspond well with the deconvolved ages. Thirty-two apatite grains were analysed and are strongly discordant, again due to the high proportions of common $\mathrm{Pb}$. Apatite crystals from this sample exhibits depletion in HREE $\left(\mathrm{Ce}_{\mathrm{N}} / \mathrm{Yb}_{\mathrm{N}}=4.85-19.83\right.$; mean value of 11.74), with pronounced negative $\mathrm{Eu}$ anomalies $\left(\mathrm{Eu} / \mathrm{Eu}^{*}=0.13-0.45\right.$; mean value of 0.30 ) and positive $\mathrm{Ce}$ anomalies ( $\mathrm{Ce} / \mathrm{Ce}^{*}=4.22-4.71$; mean value of 4.42; Table S9). Excluding 2 analyses, 30 data points lie on a Tera-Wasserburg discordia with a lower intercept age of $2260 \pm 38 \mathrm{Ma}$ (MSWD = 1.7; Table S8, Fig. 8b). This is a similar age to that obtained from apatite in sample L1429, although the ages do not overlap at the $2 \sigma$ level.

\subsection{Sample L1450, Shuldham Island}

Twenty monazite grains were analysed by EMP, and a total of 30 data points yield a mean age of $2676 \pm 15$ Ma (MSWD $=0.7$; Fig. 6e, Table S11). Grains separated from the same sample were also analysed by SHRIMP and all data are concordant. Excluding two younger analyses, 11 data from 13 grains yield a mean ${ }^{207} \mathrm{~Pb} /{ }^{206} \mathrm{~Pb}$ age of $2708 \pm 3$ Ma (MSWD = 1.5; Fig. 7d, Table S12).

\subsection{Sample L1487, Little Ramah Bay}

Six grains of monazite were analysed by EMP. Excluding two outliers of $2296 \mathrm{Ma}$ and $3452 \mathrm{Ma}, 23$ data points yield a mean age of 

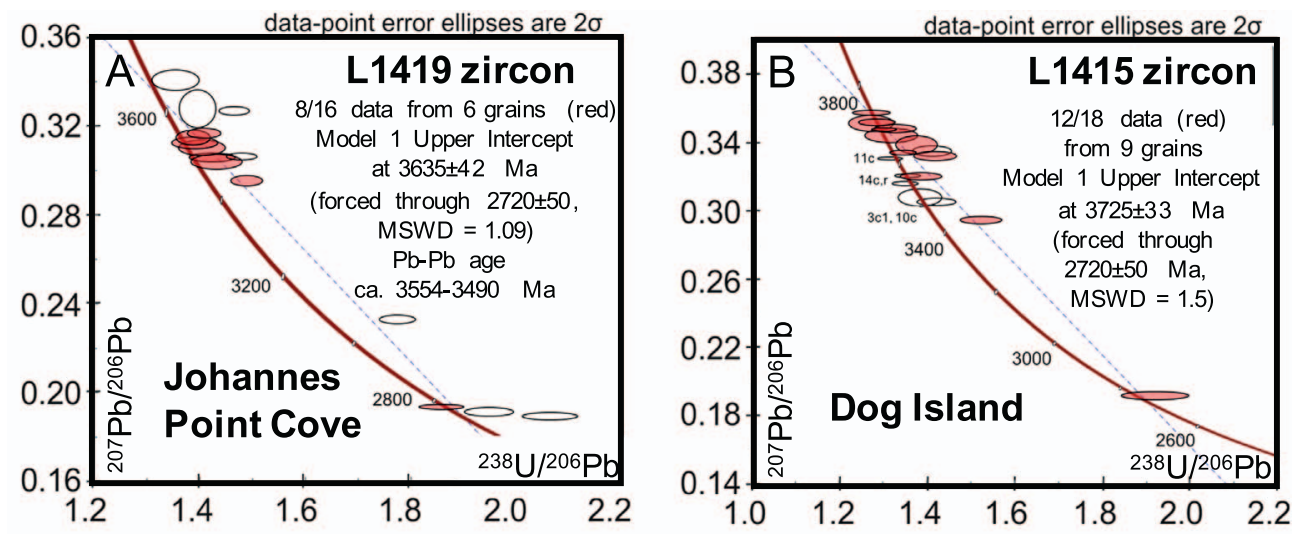

Fig. 7. Tera-Wasserburg concordia diagrams for SIMS dating of zircon (A, B, C) and monazite (D); A) sample L1419, Johannes Point Cove; B) sample L1415, Dog Island; C) sample L1429, Nulliak Island; D) sample L1450, Shuldham Island; Data with common $\mathrm{Pb}>1 \%$ are not shown. Colored ellipses show data used in age calculation. Yellow - monazite; red - zircon. (For interpretation of the references to colour in this figure legend, the reader is referred to the web version of this article.)
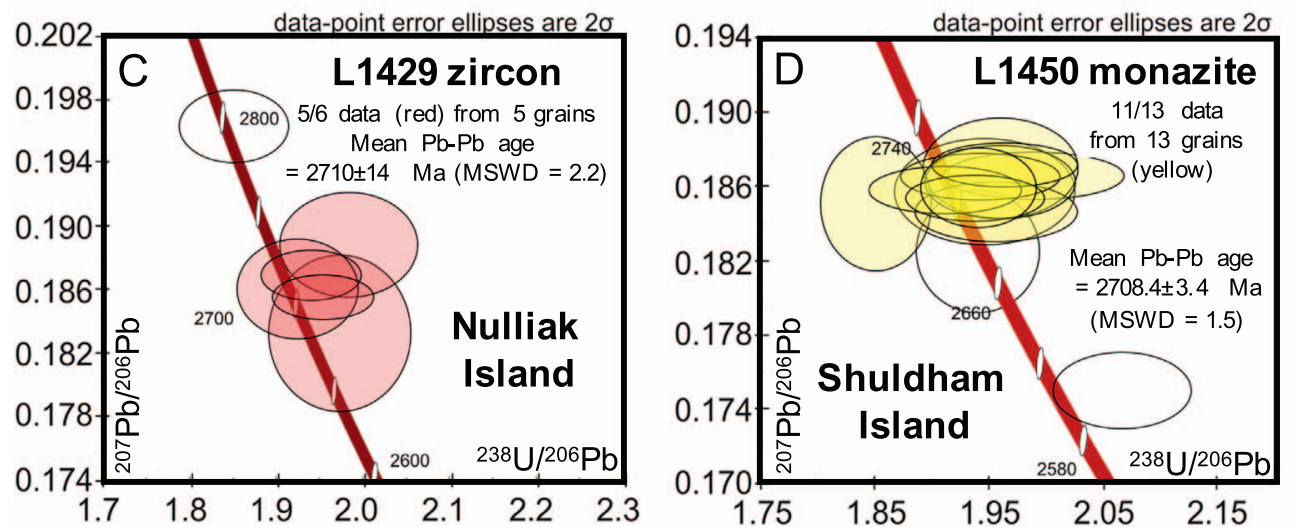

$2724 \pm 26$ Ma (MSWD = 1.1; Fig. 6f, Table S13).

\section{Discussion}

\subsection{Geochronological data interpretation}

\subsubsection{Sample L1419, Johannes Point Cove}

The monazite mean ages of $2660 \pm 22 \mathrm{Ma}$ and $2515 \pm 41$ Ma can be considered as maximum and minimum ages, respectively, for monazite growth and/or resetting. The older deconvolved age corresponds well with the maximum age. The match between the younger ages, however, is only just within $2 \sigma$, and relies on relatively few analyses. Thus we only consider the older deconvolved age $(2660 \pm 18 \mathrm{Ma})$ as providing the timing of monazite growth and/or resetting during metamorphism. For this dataset we cannot rule out the possibility of monazite growth at other times within the range of apparent ages.

The zircon U-Pb data yielded an upper intercept age of $3635 \pm 42 \mathrm{Ma}$. However, the most concordant data from zircon cores are significantly younger than the intercept age, with $\mathrm{Pb}-\mathrm{Pb}$ ages scattered between 3554 and $3490 \mathrm{Ma}$. Thus the upper intercept age is regarded as a maximum age for the magmatic protolith, while the true age may be as young as ca. $3.5 \mathrm{Ga}$. Older outliers can be attributed to the presence of xenocrystic zircon.

\subsubsection{Sample L1415, Dog Island}

Monazite results define two Gaussian populations at $2625 \pm 22 \mathrm{Ma}$ and $2519 \pm 23 \mathrm{Ma}$. The oldest subset yields a mean age of $2615 \pm 19 \mathrm{Ma}$, whereas the youngest subset can be considered as statistically equivalent with a mean age of $2540 \pm 18 \mathrm{Ma}$. These mean ages can be considered as maximum and minimum ages for monazite growth. As the deconvolved ages correspond well with these, we consider the Gaussian populations to be the best estimates for monazite growth and/or resetting during metamorphism. However, we cannot rule out the possibility of monazite growth at other times within the range of apparent ages. These ages are significantly younger than ca. $2.7 \mathrm{Ga}$ estimates from the literature.

The upper intercept age of zircon analyses at $3725 \pm 33 \mathrm{Ma}$ (MSWD $=1.5$ ) is interpreted as the age of the magmatic protolith. Four outliers scatter along concordia between $3621 \mathrm{Ma}$ and $3437 \mathrm{Ma}$, and are interpreted as being affected by metamorphism. An alternative interpretation is that the ca. $3.7 \mathrm{Ga}$ age is from xenocrystic zircon, but there is no supporting evidence for this. Our ages confirm previous estimates for the formation age of Uivak I protoliths (Schiøtte et al., 1989a, b; Krogh and Kamo, 2006), instead of the > 3.8 Ga estimate for both Uivak I protolith formation and metamorphism (Shimojo et al., 2016).

\subsubsection{Sample L1429, Nulliak Island}

The monazite EMP age of $2462 \pm 14 \mathrm{Ma}$ is significantly younger than the zircon age of $2710 \pm 14 \mathrm{Ma}$. The internal euhedral concentric growth zoning, typical of igneous zircon, and the recrystallized texture of the meta-granite, indicate that this sample is early- to syn-tectonic and intruded the Nulliak Assemblage at 2710 Ma. A 2796 Ma zircon is interpreted as xenocrystic. The monazite age can be interpreted in two ways: 1) monazite growth at ca. 2.7 with resetting at $2.5 \mathrm{Ga}$, or 2) monazite grew during a $2.5 \mathrm{Ga}$ metamorphic event.

The apatite age of $2182 \pm 27 \mathrm{Ma}$ in sample L1429 is significantly younger than the monazite age. Considering that the closure temperature for $\mathrm{Pb}$ diffusion in apatite $\left(350-500{ }^{\circ} \mathrm{C}\right.$; Cherniak et al., 1991) is lower than peak conditions for the formation of the host gneiss, the age could be interpreted as cooling subsequent to high-grade metamorphism at ca. $2.5 \mathrm{Ga}$. However, considering the intergrowth of allanite and apatite in grains associated with granoblastic monazite (Fig. 3g), and the presence of fluid-assisted re-equilibration textures, an alternative interpretation is that it formed, or re-crystallized, in a subsequent greenschist-facies metamorphic event at ca. $2.2 \mathrm{Ga}$. 

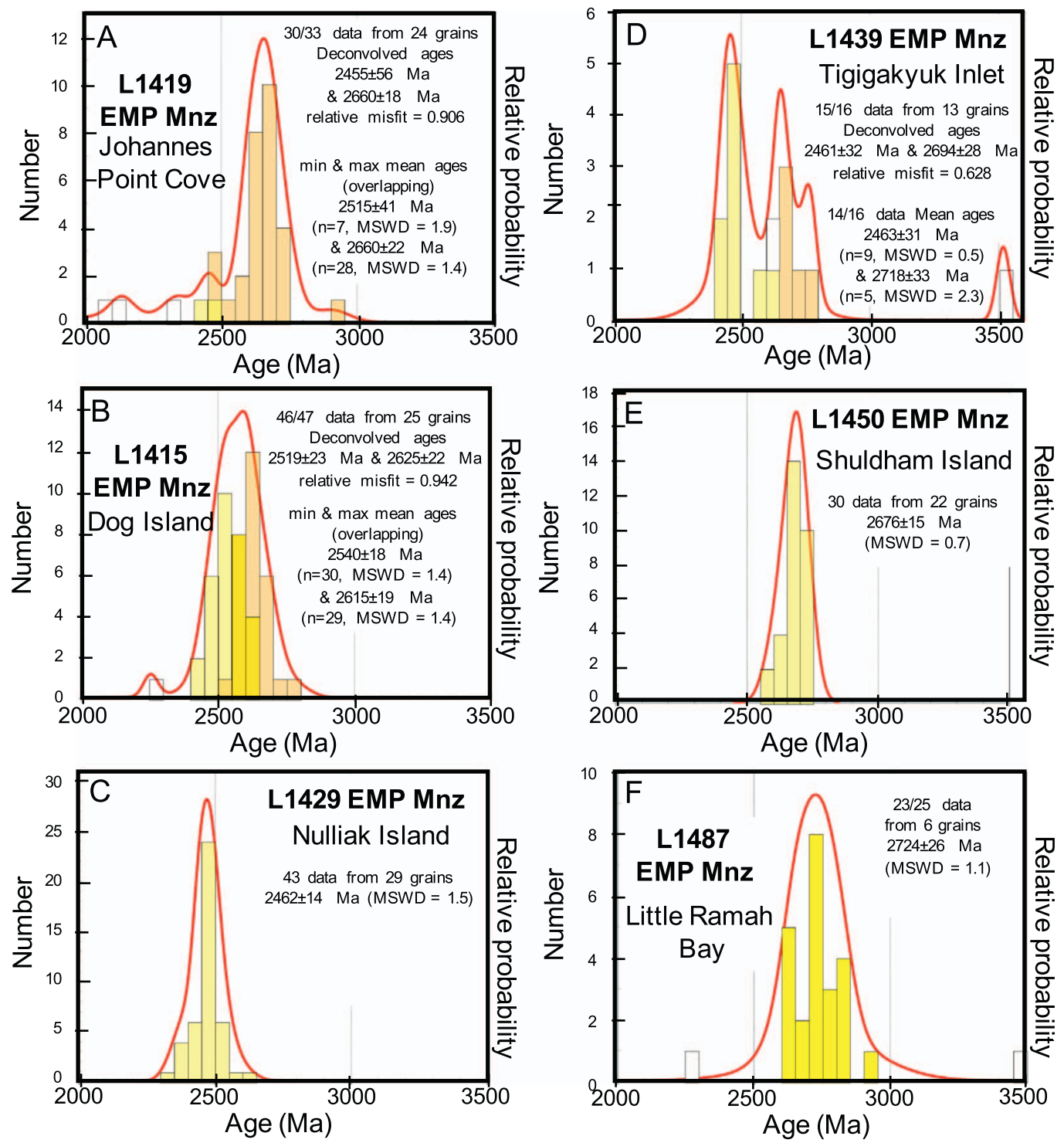

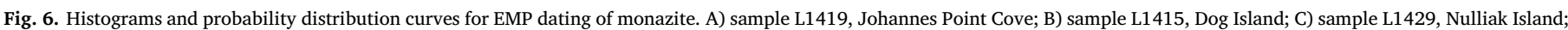

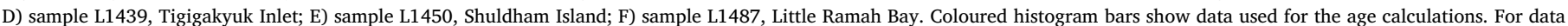

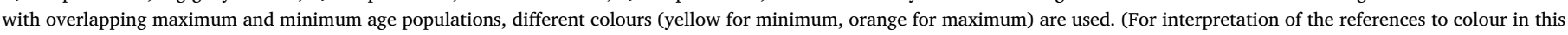
figure legend, the reader is referred to the web version of this article.)

\subsubsection{Sample L1439, Tigigakyuk Inlet}

The deconvolved monazite ages of $2694 \pm 28 \mathrm{Ma}$ and $2461 \pm 32 \mathrm{Ma}$ are interpreted as the timing of monazite growth and/ or resetting during separate metamorphic events. The older outlier of ca. $3517 \mathrm{Ma}$ is interpreted as dating monazite preserved from the protolith of the tonalitic orthogneiss.

Apatite ages of $2260 \pm 38 \mathrm{Ma}$ are similar to those obtained from apatite in sample L1429, although they just fail to overlap at the $2 \sigma$ level. They can also be attributed to fluid activity.

\subsubsection{Sample L1450, Shuldham Island}

The EMP monazite age of $2676 \pm 15 \mathrm{Ma}$ is slightly younger than the SHRIMP age mean ${ }^{207} \mathrm{~Pb} /{ }^{206} \mathrm{~Pb}$ age of $2708 \pm 3 \mathrm{Ma}$, and the latter is preferred as the time of monazite growth as it is consistent with zircon growth during high-grade metamorphism in the area. The age difference may be attributed to modification of monazite by fluids during the waning stages of the ca. $2.7 \mathrm{Ga}$ event.

\subsubsection{Sample L1487 Little Ramah Bay}

The EMP monazite age of $2724 \pm 26 \mathrm{Ma}$ is in agreement with the ca. $2.7 \mathrm{Ga}$ age from the Saglek Block in the literature (e.g. Schiøtte et al., 1992, Wasteneys et al., 1996). The older outlier of $3452 \mathrm{Ma}$ is interpreted as monazite preserved from the protolith of the meta-andesite.

\subsection{Petrographic considerations in accessory mineral dating}

Most of the monazite grains grew at grain boundaries in granoblastic assemblages, and are texturally equilibrated with the adjacent phases: monazite also occurs as inclusions in quartz (Fig. 2). Where monazite is preserved in between grain boundaries, multiple stages of monazite growth and/or resetting may be observed in a single grain, e.g. $2.5 \mathrm{Ga}$ resetting of $2.7 \mathrm{Ga}$ monazite in grain 6 of sample L1415 (Fig. 3A). In such cases, we suggest that monazite grown under peak metamorphic conditions was modified by ingress of fluids that travelled along grain boundaries. Where monazite occurs as inclusions in quartz grains, isolated from grain boundaries and possibly cracks, the quartz shields the monazite from fluid or recrystallization-induced changes during metamorphism. Thus, in the example shown in Fig. $2 \mathrm{~b}$ from sample L1439, monazite preserves a pre-metamorphic component 
yielding an apparent age of ca. $3.52 \mathrm{Ga}$. Such inclusions, therefore, make good micro-analytical targets for investigating the earlier history of metamorphic terranes.

The apatite-allanite coronas commonly found around monazite are comprised of an internal zone of apatite that replaces the margins of monazite grains, and an external zone of subhedral allanite crystals that grade outwards into REE-rich epidote and then REE-poor epidote (e.g. Fig. 3b, d). The outer coronas are typically intergrown with albite, sericite and other retrograde minerals, and replace plagioclase (Fig. 3d, i). Breakdown of biotite and/or Fe-Ti oxides contribute Fe to the formation of allanite and epidote. This occurs even where such minerals are not adjacent to the monazite, demonstrating that fluids are required for the reaction to proceed (Finger et al., 1998; Yi and Cho, 2009). Fluids have also assisted the modification of apatite grains, re-equilibrating LREE-enriched apatite to LREE-depleted apatite plus micro-inclusions of monazite. The presence of tiny inclusions of monazite in apatite is characteristic of fluid-assisted coupled dissolution-precipitation, and suggestive of re-equilibration after grain formation (e.g. Harlov, 2011, 2015; Harlov et al., 2002, 2005; Harlov and Förster, 2003). Experimental results (Budzyń et al., 2011; Budzyń et al., 2017) are consistent with natural observations that fluid activity is just as important as changes in P-T conditions for monazite breakdown reactions (Finger et al., 1998, 2016; Janots et al., 2008; Ondrejka et al., 2012, 2016). The formation of monazite micro-inclusions in apatite may not be coeval with the breakdown of granoblastic monazite to apatite-allanite; the former may have been produced at different temperatures by fluids that were also responsible for monazite resetting at ca. 2.5 Ga (cf. Grand'Homme et al., 2016, 2017; Kelly et al., 2012). Investigations are underway to resolve this issue, and to test the association of accessory minerals produced by fluid infiltration processes with metamorphic events in the Nain Province.

\subsection{Thermal history of the Saglek Block}

A granulite-facies metamorphic event between 2.8 and $2.7 \mathrm{Ga}$ is well documented in the literature from Saglek Fjord (Fig. 9). Metamorphic zircon with an age of $2727 \pm 7 \mathrm{Ma}$ (Schiøtte et al., 1992) was identified in metasedimentary gneiss from outer Saglek Bay. The age of peak metamorphism was dated by zircon at $2760 \pm 6$ Ma (Nutman and Collerson, 1991) and $2761 \pm 12 \mathrm{Ma}$ (Schiøtte et al., 1992) from quartzite near St. John's Harbour and Torr Bay, respectively. North of Saglek Fjord, similar ages were documented around Nachvak Fjord, including $2701 \pm 80$ Ma from Mount Razorback (Wanless et al., 1970) and $2693 \pm 120 \mathrm{Ma}$, based on $\mathrm{Rb} / \mathrm{Sr}$ whole-rock analyses of six orthogneisses from the south shore of Nachvak Fjord (Collerson et al., 1982). To the south of Saglek Fjord, beyond the study area shown on Fig. 1, metamorphic zircon ages of $2793 \pm 3 \mathrm{Ma}$ and $2780 \pm 3 \mathrm{Ma}$ were obtained from Drachart Island (Schiøtte and Bridgwater, 1990; Schiøtte et al., 1990). These authors suggested the ages are slightly older because of the incorporation of relict zircon.

An upper amphibolite- to granulite-facies metamorphic event is also recorded by the growth of zircon and monazite in samples from this study. Our sample of intermediate orthogneiss collected from Little Ramah Bay yields a U-Pb metamorphic monazite age of $2724 \pm 26 \mathrm{Ma}$. A similar U-Pb age of $2708 \pm 3$ Ma was obtained by SHRIMP from monazite in pelitic gneiss from Shuldham Island (Fig. 7d). This matches the $2710 \pm 14$ Ma zircon age for syn-tectonic meta-granite from Nulliak Island. Monazite from Tigigakyuk Inlet records an age of $2694 \pm 28 \mathrm{Ma}$, whereas monazites from Nulliak Island and Dog Island are significantly younger $(2660 \pm 18 \mathrm{Ma}$ and $2625 \pm 22 \mathrm{Ma}$, respectively). This spread of ages suggests that the ca. $2.7 \mathrm{Ga}$ event was prolonged over a period of $>50$ million years, although it is not known if it represents progressive metamorphism maintained at high temperatures over this period, or a succession of thermal pulses. More precise geochronology tied to detailed petrographic work is required to resolve this issue.

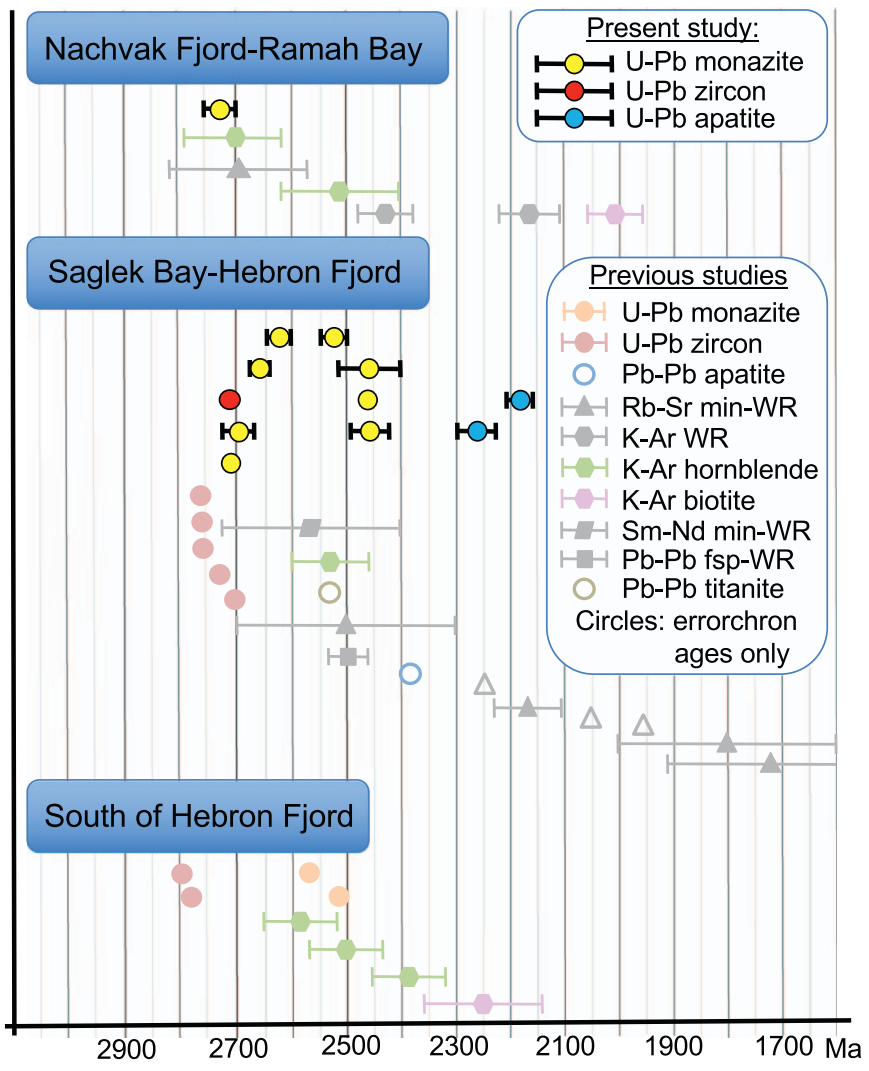

Fig. 9. Geochronological data defining metamorphic events in northern Labrador; grey square - Pb-Pb data from feldspar and titanite (Baadsgaard and Collerson, 1979; Wendt and Collerson, 1999); grey rhombus - Sm-Nd data (Wendt and Collerson, 1999); grey hexagon - K-Ar hornblende, biotite and whole rock data (Barton, 1975; Leech et al., 1963; Wanless et al., 1970; Wanless et al., 1974; Wanless et al., 1979b; Wanless et al., 1965); grey triangle - Rb-Sr biotite and whole-rock data (Collerson, 1983a; Collerson et al., 1982); orange circle - U-Pb monazite data (Schiøtte et al., 1990), light pink circle - U-Pb zircon data (Schiøtte and Bridgwater, 1990; Schiøtte et al., 1989b; Wanless et al., 1979a), light blue circle - Pb-Pb apatite data (Baadsgaard and Collerson, 1979; Nutman and Collerson, 1991; Schiøtte et al., 1989a; Schiøtte et al., 1989b; Schiøtte et al., 1992). Data from the present study are marked by circles in yellow - U-Pb monazite, red - U-Pb zircon and blue - $\mathrm{Pb}-\mathrm{Pb}$ apatite; note that two zircon samples from the present study, where zircon age was interpreted as the protolith age, are not presented in the figure. Data where error bars are invisible means they are smaller than the symbol. (For interpretation of the references to colour in this figure legend, the reader is referred to the web version of this article.)

Previous authors have all ascribed the formation of upper amphibolite to granulite facies gneisses in the Saglek Block to metamorphism at ca. $2.7 \mathrm{Ga}$. However the intrusion of granitic dykes and sheets, as well as cooling ages for various isotopic systems, have also been reported at ca. $2.5 \mathrm{Ga}$. On Maidmonts Island, several orthogneisses yielded a Rb-Sr whole-rock age of $2497 \pm 200 \mathrm{Ma}$ (Collerson, 1983b), a K/Ar hornblende age of $2532 \pm 62 \mathrm{Ma}$ (Wanless et al., 1974) and a garnet-pyroxene-whole rock $\mathrm{Sm} / \mathrm{Nd}$ isochron age of $2570 \pm 171 \mathrm{Ma}$ (Wendt and Collerson, 1999). In the Kikyuktok area of Saglek Fjord, a $\mathrm{Pb}-\mathrm{Pb}$ feldspar-whole rock isochron from a garnet pyroxenite recorded an age of $2496 \pm 38 \mathrm{Ma}$ (Wendt and Collerson, 1999). Zircon dating of augen gneiss by Wanless et al. (1979a) recorded a lower intercept age of $2492 \pm 80 \mathrm{Ma}$, which was interpreted as the timing of $\mathrm{Pb}$ loss in the sample. A ca. $2530 \mathrm{Ma}$ titanite U-Pb "errorchron" was obtained from Nulliak and Uivak gneisses from the southern shore of Big Island (Baadsgaard and Collerson, 1979). On the north shore of Reddick Bight, $50 \mathrm{~km}$ north of Saglek Bay, a K/Ar hornblende age of $2531 \pm 128 \mathrm{Ma}$ (Wanless et al., 1965) was obtained from mafic orthogneiss, whereas $50 \mathrm{~km}$ south of Hebron Fjord, in the Mugford Bay area, K/Ar hornblende ages of $2590 \pm 14 \mathrm{Ma}$ and $2500 \pm 14 \mathrm{Ma}$ from migmatites have been reported (Barton, 1975). The only previous monazite 
geochronology undertaken on the Saglek Block (Schiøtte et al., 1990) was performed on a leucocratic granitoid sheet from Parkavik Island near Mugford Bay, yielding an igneous U-Pb age of $2510 \pm 10 \mathrm{Ma}$, and on an orthogneiss from Drachart Island, $20 \mathrm{~km}$ south of Hebron Fjord, yielding a U-Pb age of $2570 \pm 10 \mathrm{Ma}$. Both ages were interpreted by Schiøtte et al. (1990) as being associated with the emplacement of posttectonic granites. Our new monazite results from felsic orthogneisses include ages of $2519 \pm 23 \mathrm{Ma}$ from Dog Island (sample L1415), $2455 \pm 56 \mathrm{Ma}$ from Johannes Point Cove (L1419) and $2461 \pm 32 \mathrm{Ma}$ from Tigigakyuk Inlet (L1439), as well as a mean age of $2462 \pm 14 \mathrm{Ma}$ from fine-grained meta-granite from Nulliak Island (L1429). These results are slightly younger than those obtained further south by Schiøtte et al. (1990), but, along with the whole-rock and mineral cooling ages from Nachvak Fjord to Mugford Bay, indicate the occurrence of a widespread metamorphic event of sufficient temperature to induce monazite re-equilibration and growth in ca. $2.7 \mathrm{Ga}$ gneisses. The presence of $2.5 \mathrm{Ga}$ granitoid sheets and dykes suggests that temperatures were sufficient for partial melting, although this has still to be established. The ca. $2.5 \mathrm{Ga}$ event may be associated with the reworking of the ca. $2.7 \mathrm{Ga}$ suture between the Saglek and Hopedale blocks, as suggested by Wasteneys et al. (1996).

Ages younger than $2.4 \mathrm{Ga}$ have been obtained using various chronometers from the Saglek Block. A zircon Pb-loss intercept age of $2355 \pm 12 \mathrm{Ma}$ (Schiøtte et al., 1989b) and a Rb-Sr biotite-whole rock "errorchron" of ca. $2246 \mathrm{Ma}$ have been obtained for grey gneiss from Ukkalek Island, south of Nulliak Island (Collerson, 1983a). Felsic orthogneisses from the north shore of Hebron Fjord yielded Rb-Sr wholerock cooling ages of $1813 \pm 200 \mathrm{Ma}$ and $1715 \pm 200 \mathrm{Ma}$, and a ca. 1960 Ma biotite - whole-rock "errorchron" (Collerson, 1983a). Similar "errorchrons" have been obtained for felsic orthogneiss from Maidmonts Island. Near Little Ramah Bay, a K-Ar biotite cooling age of $2006 \pm 46$ Ma was obtained from a granite at Duncan Point (Wanless et al., 1979b). South of Hebron Fjord, in the Mugford Bay area, a migmatite recorded a K-Ar hornblende age of $2394 \pm 13 \mathrm{Ma}$ (Barton, 1975 ) and a paragneiss recorded a K-Ar biotite age of $2248 \pm 115 \mathrm{Ma}$ (Leech et al., 1963), both of which are likely to be cooling ages.

The closure temperate of $\mathrm{Pb}$ diffusion in apatite is $\sim 350-500{ }^{\circ} \mathrm{C}$ (Cherniak et al., 1991; Schoene and Bowring, 2007). The U-Pb apatite ages in this study $(2188 \pm 47 \mathrm{Ma}$ for sample L1429 and $2258 \pm 71$ Ma for sample L1439) are broadly consistent with published ages from mineral systems with similar closure temperatures, such as K-Ar in hornblende. Thus, it is possible that apatite records the time of progressive cooling after the $2.5 \mathrm{Ga}$ and/or $2.7 \mathrm{Ga}$ high-temperature events, although the time interval appears far too long given that monazite records episodes of growth/recrystallization between these extremes. Alternatively, the apatite ages may record new apatite growth, such as that which produced apatite + allanite-epidote coronas around monazite, or by fluid-assisted resetting of pre-existing grains, as evidenced by grains in textural equilibrium with granoblastic assemblages that contain micro-inclusions of monazite. Both processes can be achieved by an influx of hydrous fluids under greenschist facies conditions. In all cases, the ages do not record the timing of apatite growth in the peak metamorphic assemblage, but modification through diffusion or fluid activity at a later time. Whether the ages represent the final stages of retrograde metamorphism after the $2.5 \mathrm{Ga}$ high-temperature event, or a discrete episode of metamorphism, remains uncertain. It is worth noting, however, that these ages are significantly older than the 1.8-1.7 Ga timing of metamorphism during the Torngat Orogeny (Van Kranendonk, 1996) which strongly affects the margins of the Saglek Block and its adjacent terranes.

One thing that has become evident from this study is that individual samples can record multiple events, even utilizing the same isotopic system (U-Th-Pb), when multiple mineral phases (monazite, zircon and apatite) are analysed. Sample L1429 of syn-tectonic meta-granite from Nulliak Island is an excellent example of how different minerals respond to a protracted thermal history. Zircon grains preserve the
$2.71 \mathrm{Ga}$ crystallization age, recording intrusion into the Nulliak Assemblage during granulite-facies metamorphism and high-strain ductile deformation. Monazite grains are likewise granoblastic and therefore would have been present during the $2.7 \mathrm{Ga}$ metamorphism. However, the consistent ca. $2.46 \mathrm{Ga}$ ages obtained from many grains is an indication that monazite has been thoroughly reset by a later tectonothermal event. High-temperature $2.5 \mathrm{Ga}$ metamorphism has not previously been recognized in the area, except in association with the intrusion of granitoid sheets and dykes. Apatite from the same sample also yields ages that are younger than its inferred timing of crystallization; however these are at $2.2 \mathrm{Ga}$ not $2.5 \mathrm{Ga}$. This can be interpreted as either cooling through $\sim 500{ }^{\circ} \mathrm{C}$ at ca. $2.2 \mathrm{Ga}$ following the ca. $2.5 \mathrm{Ga}$ metamorphic event, or alternatively as a separate, greenschist-facies metamorphic event at ca. $2.2 \mathrm{Ga}$. Hydrous retrogression of this and many other rocks from the Saglek Block may therefore be associated with a previously unknown tectonic event at ca. $2.2 \mathrm{Ga}$. Whether this represent a separate event or records the earliest stages of the TransHudson Orogeny remains unknown. But it is clear that whatever the cause, this predates the Torngat Orogeny dated at $1.8-1.7 \mathrm{Ga}$.

\section{Conclusions}

This study of high-grade rocks from the Saglek Block leads to the following conclusions.

1. Zircon dating confirms 3.7-3.6 Ga protolith ages for tonalitic Uivak orthogneisses as obtained in previous studies. We found no evidence of zircon growth before $3.85 \mathrm{Ga}$.

2. The area was strongly affected by high-grade metamorphism at ca. $2.7 \mathrm{Ga}$, as evidenced by monazite growth in Uivak gneisses and intrusion of syn-tectonic granitoid as recorded by igneous zircon. Metamorphism occurred over a period of at least 50 m.y. down to ca. $2.6 \mathrm{Ga}$.

3. Monazite also reveals geological activity at $2.5 \mathrm{Ga}$ that can be attributed to hydrous infiltration. This corresponds to known granitic activity at this time, especially to the south of the Hebron Fjord. This may or may not be related to a discrete metamorphic event.

4. Apatite has ca. $2.2 \mathrm{Ga}$ ages that can be attributed to fluid-induced modification, as indicated by coupled dissolution-precipitation textures, such as monazite inclusions in apatite. This is most likely associated with a previously unrecognized greenshist-facies metamorphic event that predates the Torngat Orogeny.

Supplementary data to this article can be found online at https:// doi.org/10.1016/j.chemgeo.2017.10.033.

\section{Acknowledgements}

This research was supported by a grant to MAK from the Polish National Science Centre; NCN (nr 2014/15/B/ST10/04245), grants to MJW from the Knut and Alice Wallenberg Foundation (2012.0097) and the Swedish Research Council (2012-4370), a Science Foundation Ireland grant 12/IP/1663 awarded to DC, and the Australian Research Council Centre of Excellence for Core to Crust Fluid Systems (CCFS). This is NordSIMS contribution no. 525. We wish to thank Klaus Mezger for handling the manuscript and Emily Janots and an anonymous reviewer for careful reviews. Fieldwork was carried out with the permission and support of Parks Canada (special thanks to Darroch Whitaker) and the Nunatsiavut Government.

\section{References}

Aleinikoff, J.N., Schenck, W.S., Plank, M.O., Srogi, L.A., Fanning, C.M., Kamo, S., Bosbyshell, H., 2006. Deciphering igneous and metamorphic events in high-grade rocks of the Wilmington complex, Delaware: morphology, cathodoluminescence and backscattered electron zoning, and SHRIMP U-Pb geochronology of zircon and 
monazite. Geol. Soc. Am. Bull. 118, 605-626.

Åmli, R., Griffin, W.L., 1975. Microprobe analysis of REE minerals using empirical correction factors. Am. Mineral. 60, 599-606.

Baadsgaard, H., Collerson, K.D., 1979. The Archean gneiss complex of northern Labrador. 1. Preliminary U—Th—Pb geochronology. Can. J. Earth Sci. 16, 951-961.

Barton, J.M., 1975. The Mugford group volcanics of Labrador: age geochemistry and tectonic. Can. J. Earth Sci. 12, 1196-1208.

Bridgwater, D., Schiøtte, L., 1991. The Archaean gneiss complex of northern Labrador, a review of current results, ideas and problems. Bull. Geol. Soc. Den. 39, 153-166.

Bridgwater, D., Collerson, K.D., Hurst, R.W., Jesscau, C.W., 1975. Field Characters of the Early Precambrian Rocks From Saglek, Coast of Labrador. Department of Energy, Mines and Resources, Geological Survey of Canada, Ottawa.

Bridgwater, D., Mengel, F., Schiøtte, L., Winter, J., 1990. Research on the Archean Rocks of Northern Labrador, Progress Report. Current Research Newfoundland Department of Mines and Energy, Geological Survey Branch, Report. 90-1. pp. 227-236.

Budzyń, B., Harlov, D.E., Williams, M.L., Jercinovic, M.J., 2011. Experimental determination of stability relations between monazite, fluorapatite, allanite, and REE-epidote as a function of pressure, temperature, and fluid composition. Am. Mineral. 96, 1547-1567.

Budzyń, B., Harlov, D.E., Kozub-Budzyń, G.A., Majka, J., 2017. Experimental constraints on the relative stabilities of the two systems monazite-(Ce) - allanite-(Ce) - fluorapatite and xenotime-(Y) - (Y,HREE)-rich epidote - (Y,HREE)-rich fluorapatite, in high Ca and Na-Ca environments under P-T conditions of 200-1000 MPa and 450-750 ${ }^{\circ} \mathrm{C}$. Mineral. Petrol. 111, 183-217.

Cherniak, D.J., Lanford, W.A., Ryerson, F.J., 1991. Lead diffusion in apatite and zircon using ion-implantation and Rutherford backscattering techniques. Geochim. Cosmochim. Acta 55 (6), 1663-1673.

Chew, D.M., Donelick, R.A., 2012. Combined apatite fission track and U-Pb dating by LAICPMS and future trends in apatite provenance analysis. In: Sylvester, P. (Ed.), Quantitative Mineralogy and Microanalysis of Sediments and Sedimentary Rocks. Mineralogical Association of Canada, pp. 219-248.

Chew, D.M., Petrus, J.A., Kamber, B.S., 2014. U-Pb LA-ICPMS dating using accessory mineral standards with variable common Pb. Chem. Geol. 363, 185-199.

Chew, D.M., Babechuk, M.G., Cogné, N., Mark, C., O'Sullivan, G.J., Henrichs, I.A., Doepke, D., McKenna, C.A., 2016. (LA,Q)-ICPMS trace-element analyses of Durango and McClure Mountain apatite and implications for making natural LA-ICPMS mineral standards. Chem. Geol. 435, 35-48.

Cochrane, R., Spikings, R.A., Chew, D., Wotzlaw, J.-F., Chiaradia, M., Tyrrell, S., Schaltegger, U., Van der Lelij, R., 2014. High temperature $\left(>350{ }^{\circ} \mathrm{C}\right)$ thermochronology and mechanisms of Pb loss in apatite. Geochim. Cosmochim. Acta 127, $39-56$.

Collerson, K.D., 1983a. The Archean gneiss complex of northern Labrador. 2. Mineral ages secondary isochrons and diffusion of strontium during polymetamorphism of the Uivak gneisses. Can. J. Earth Sci. 20, 707-718.

Collerson, K.D., 1983b. Ion Microprobe Zircon Geochronology of the Uivak Gneisses: Implicaitons for the Evolution of Early Terrestial Crust in the North Atlantic Craton. Lunar and Planetary Institute Technical Report, Houston, Texas.

Collerson, K.D., Bridgwater, D., 1979. Metamorphic development of early Archaean tonalitic and Trondhjemitic gneisses: Saglek area, Labrador. In: Barker, F. (Ed.), Trondhjemites, Dacites, and Related Rock. Elsevier, Amsterdam, pp. 205-271.

Collerson, K.D., Kerr, A., Vocke, R.D., Hanson, G.N., 1982. Reworking of sialic crust as represented in late Archaean-age gneisses, northern Labrador. Geology 10, 202-208.

Collerson, K.D., Meroz, Y., Gil, C., 1992. Early Archean lithosphere: constraints from the North Atlantic Craton. Eos 73, 330.

Dunkley, D.J., Suzuki, K., Hokada, T., Kusiak, M.A., 2008. Contrasting ages between isotopic chronometers in granulites: monazite dating and metamorphism in the Higo complex, Japan. Gondwana Res. 14, 624-643.

Ermanovics, I.F., Van Kranendonk, M., Corriveau, L., Mengel, F., Bridgwater, D., Sherlock, R., 1988. Geology of North River-Nutak map areas, Nain-Churchill provinces, Labrador. Geological Survey of Canada, Report 88 (1C), 19-26.

Ermanovics, I.F., Van Kranendonk, M., Corriveau, L., Mengel, F., Bridgwater, D., Sherlock, R., 1989. The boundary zone of the Nain-Churchill provinces in the North River-Nutak map areas, Labrador. Geological Survey of Canada, Report 89 (1C), 385-394.

Finger, F., Broska, I., Roberts, M.P., Schermaier, A., 1998. Replacement of primary monazite by apatite-allanite-epidote coronas in the amphibolite facies granite gneiss from the eastern Alps. Am. Mineral. 83, 248-258.

Finger, F., Krenn, E., Schultz, B., Harlov, D., Schiller, D., 2016. "Satellite monazites" in polymetamorphic basement rocks of the alps: their origin and petrological significance. Am. Mineral. 110, 1094-1103.

Fletcher, I.R., McNaughton, N.J., Davis, W.J., Rasmussen, B., 2010. Matrix effects and calibration limitations in ion probe U-Pb and Th- $\mathrm{Pb}$ dating of monazite. Chem. Geol. 270 (1-4), 31-44.

Grand'Homme, A., Janots, E., Seydoux-Guillaume, A.M., Guillaume, D., Bosse, V., Magnin, V., 2016. Partial resetting of the U-Th-Pb systems in experimentally altered monazite: nanoscale evidence of incomplete replacement. Geology 44, 431-434.

Grand'Homme, A., Janots, E., Seydoux-Guillaume, A.M., Guillaume, D., Magnin, V., Hövelmann, J., Höschen, C., Boiron, C., 2017. Mass transport and fractionation during monazite alteration by anisotropic replacement. Chem. Geol. http://dx.doi. org/10.1016/j.chemgeo.2017.10.008. this issue.

Harlov, D.E., 2011. Formation of monazite and xenotime inclusions in fluoroapatite megacrysts, Gloserheia granite pegmatite, Florland, Bamble sector, southern Norway. Mineral. Petrol. 102, 77-86.

Harlov, D.E., 2015. Apatite: a fingerprint for metasomatic processes. Elements 11, $171-176$.

Harlov, D.E., Förster, H.-J., 2003. Fluid-induced nucleation of (Y + REE)-phosphate minerals within apatite: nature and experiment. Part II. Fluoroapatite-monazite relationships in granulite-facies metapelites, Schwarzwald, southwest Germany. Mineral. Mag. 71, 223-234.

Harlov, D.E., Andersson, U.B., Förster, H.-J., Nyström, J.O., Dulski, P., Broman, C., 2002. Apatite-monazite relations in the Kiirunavaara magnetite-apatite ore, northern Sweden. Chem. Geol. 191, 47-72.

Harlov, D.E., Wirth, R., Förster, H.-J., 2005. An experimental study of dissolution-reprecipitation in fluoroapatite: fluid infiltration and the formation of monazite. Contrib. Mineral. Petrol. 150, 268-286.

Hogdahl, K., Majka, J., Sjostrom, H., Nilsson, K.P., Claesson, S., Konečný, P., 2012. Reactive monazite and robust zircon growth in diatexites and leucogranites from a hot, slowly cooled orogen: implications for the Palaeoproterozoic tectonic evolution of the central Fennoscandian shield, Sweden. Contrib. Mineral. Petrol. 163 (1), 167-188.

Janots, E., Engi, M., Berger, A., Allaz, J., Schwarz, J.O., Spandler, C., 2008. Prograde metamorphic sequence of REE minerals in pelitic rocks of the Central Alps: implications for allanite-monazite-xenotime phase relations from 250 to $610{ }^{\circ} \mathrm{C}$. J. Metamorph. Geol. 26, 509-526.

Jeon, H., Whitehouse, M.J., 2015. A critical evaluation of U-Pb calibration schemes used in SIMS zircon geochronology. Geostand. Geoanal. Res. 39, 443-452.

Kelly, N.M., Harley, S.L., Möller, A., 2012. Complexity in the behavior and recrystallization of monazite during high-T metamorphism and fluid infiltration. Chem. Geol. 322-323, 192-208.

Komiya, T., Yamamoto, S., Aoki, S., Sawaki, Y., Ishikawa, A., Tashiro, T., Koshida, K., Shimojo, M., Aoki, K., Collerson, K.D., 2015. Geology of the Eoarchean, > 3.95 Ga, Nulliak supracrustal rocks in the Saglek Block, northern Labrador, Canada: the oldest geological evidence for plate tectonics. Tectonophysics 662, 40-66.

Konečný, P., Siman, P., Holický, I., Janák, M., Kollárová, V., 2004. Electron Microprbe dating method (Metodika datovania monazite pomocou elektrónového mikroanalyzátora). Mineralia Slovaca 36, 225-235.

Konečný, P., Kusiak, M.A., Dunkley, D.J., 2017. Improving U-Th-Pb electron microprobe dating using monazite age references. Chem. Geol this issue.

Krogh, T.E., Kamo, S.L., 2006. Precise U-Pb zircon ID-TIMS ages provide an alternative interpretation to early ion microprobe ages and new insights into Archean crustal processes, northern Labrador. In: Reimold, W.U., Gibson, R.L. (Eds.), Processes on the early Earth: geological society of America special paper. Geol. Soc. Am., pp. 91-103.

Kusiak, M.A., Sałacińska, A., 2016. Searching for pieces of the oldest crust in Labrador (in Polish). Prz. Geol. 64, 896-901.

Leech, G.B., Lowdon, J.A., Stockwell, C.H., Wanless, R.K., 1963. Age determinations by the Geological Survey of Canada Report 4; isotopic ages. Geol. Surv. Can. Pap. 63-17, $1-121$.

Ludwig, K.R., 2001. User's Manual for Isoplot/Ex v. 3.0: A Geochronological Toolkit for Microsoft Excel. 1a. Berkeley Geochronological Center, Special Publication, pp. $1-56$.

Ludwig, K.R., 2009. Squid 2.50, A User's Manual. Berkeley Geochronology Centre, Berkeley, California, USA, pp. 1-95.

Majka, J., Be'eri-Shlevin, Y., Gee, D.G., Ladenberger, A., Claesson, S., Konečný, P. Klonowska, I., 2012. Multiple monazite growth in the Areskutan migmatite: evidence for a polymetamorphic Late Ordovician to Late Silurian evolution in the Seve Nappe complex of west-central Jamtland, Sweden. J. Geosci. 57, 3-23.

Montel, J.-M., Foret, S., Veschambre, M., Nicollet, C., Provost, A., 1996. Electron microprobe dating of monazite. Chem. Geol. 131 (1-4), 37-53.

Nutman, A.P., Collerson, K.D., 1991. Very early Archean crustal-accretion complexes preserved in the North Atlantic Craton. Geology 19, 791-794.

Ondrejka, M., Uher, P., Putiš, M., Broska, I., Bačik, P., Konečný, P., Schmiedt, I., 2012. Two-stage breakdown of monazite by post-magmatic and metamorphic fluids: an example from the Veporic orthogneiss Western Carpathians, Slovakia. Lithos 142 $143,245-255$.

Ondrejka, M., Putiš, M., Uher, P., Schmiedt, I., Pukančík, L., Konečný, P., 2016. Fluiddriven destabilization of REE-bearing accessory minerals in the granitic orthogneisses of North Veporic basement (Western Carpathians, Slovakia). Mineral. Petrol. 110, 561-580.

Paton, M., Muinonen, K., Pesonen, L.J., Kuosmanen, V., Kohout, T., Laitinen, J., Lehtinen, M., 2011. A PCA study to determine how features in meteorite reflectance spectra vary with the samples' physical properties. J. Quant. Spectrosc. Radiat. Transf. 112 (11), 1803-1814.

Petrus, J.A., Kamber, B.S., 2012. VizualAge: a novel approach to laser ablation ICP-MS U$\mathrm{Pb}$ geochronology data reduction. Geostand. Geoanal. Res. 36 (3), 247-270.

Ryan, B., 1990. Basement-cover relationships and metamorphic patterns in the foreland of the Torngat Orogen in the Saglek Hebron area, Labrador. Geosci. Can. 17, 276-279.

Ryan, A.B., Martineau, Y., Bridgwater, D., Schiøtte, L., Lewry, J., 1983. The ArcheanProterozoic Boundary in the Saglek Fiord Area, Labrador, Report 1. Newfoundland Department of Mines and Energy, Mineral Development Division.

Ryan, A.B., Martineau, Y., Korstgaad, J., Lee, D., 1984. The Archean — Proterozoic Boundary in Northern Labrador, Report. pp. 2.

Sałacińska, A., Kusiak, M.A., 2017. Preliminary petrographic studies of the Archaean Uivak gneisses, Nain Province, Labrador (in Polish). Prz. Geol. 65, 383-391.

Schiøtte, L., Bridgwater, D., 1990. Multistage Late Archean granulite facies metamorphism in Northern Labrador, Canada. Granulites and Crustal Evolution 311 , 157-169.

Schiøtte, L., Bridgwater, D., Collerson, K.D., Nutman, A.P., Ryan, A.B., 1986. Chemical and isotopic effects of Late Archean high-grade metamorphism and granite injection on Early Archean Gneisses, Saglek-Hebron, Northern Labrador. In: Dawson, J.B. Carswell, D.A., Hall, J., Wedepohl, K.H. (Eds.), The Nature of the Lower Continental Crust. Geological Society Special Publication, pp. 261-273. 
Schiøtte, L., Compston, W., Bridgwater, D., 1989a. Ion-probe U-Th-Pb zircon dating of polymetamorphic orthogneisses from Northern Labrador, Canada. Can. J. Earth Sci. 26, 1533-1556.

Schiøtte, L., Compston, W., Bridgwater, D., 1989b. U-Th-Pb ages of single zircons in Archean supracrustals from Labrador, Canada. Can. J. Earth Sci. 26, 2636-2644.

Schiøtte, L., Noble, S., Bridgwater, D., 1990. U-Pb mineral ages from northern Labrador: possible evidence for interlayering of Early and Middle Archean tectonic slices. Geosci. Can. 17 (4), 227-231.

Schiøtte, L., Nutman, A.P., Bridgwater, D., 1992. U-Pb ages of single zircons within Upernavik Metasedimentary rocks and regional implications for the tectonic evolution of the Archean -Nain Province, Labrador. Can. J. Earth Sci. 29, 260-276.

Schoene, B., Bowring, S.A., 2006. U-Pb systematics of the McClure Mountain syenite: thermochronological constraints on the age of the Ar-40/Ar-39 standard MMhb. Contrib. Mineral. Petrol. 151 (5), 615-630.

Schoene, B., Bowring, S.A., 2007. Determining accurate temperature-time paths from U$\mathrm{Pb}$ thermochronology: an example from the Kaapvaal craton, southern Africa. Geochim. Cosmochim. Acta 71 (1), 165-185.

Shimojo, M., Yamamoto, S., Sakata, S., Yokoyama, T.D., Maki, K., Sawaki, Y., Ishikawa, A., Aoki, K., Aoki, S., Koshida, K., Tashiro, T., Hirata, T., Collerson, K.D., Komiya, T., 2016. Occurrence and geochronology of the Eoarchean, 3.9 Ga, Iqaluk Gneiss in the Saglek Block, northern Labrador, Canada: evidence for the oldest supracrustal rocks in the world. Precambrian Res. 278, 218-243.

Stacey, J.S., Kramers, J.D., 1975. Approximation of terrestrial lead isotope evolution by a two-stage model. Earth Planet. Sci. Lett. 26 (2), 207-221.

Sun, S.S., McDonough, W.F., 1995. The composition of the Earth. Chem. Geol. 120, 223-253.

Van Kranendonk, M.J., 1996. Tectonic evolution of the Paleoproterozoic Torngat Orogen: evidence from pressure-temperature-time-deformation paths in the North River map area, Labrador. Tectonics 15 (4), 843-869.

Van Kranendonk, M., Helmstaedt, H., 1990. Late Archean geologic history of the Nain Province, North River-Nutak map area, Labrador, and its tectonic significance. Geosci. Can. 17, 231-237.

Vavra, G., Gebauer, D., Schmid, R., Comston, W., 1996. Multple zircon growth and recrystallization during polyphase late carboniferous to Triassic metamorphism in granulites of the Ivrea zone (Southern Alps): an ion microprobe (SHRIMP) study. Contrib. Mineral. Petrol. 122, 337-358.
Wanless, R.K., Stevens, R.D., Lachance, G.R., Rimsaite, J.Y.H., 1965. Isotopic ages report 5; age determinations and geological studies part 1. Geol. Surv. Can. Pap. 64-17, 11-126.

Wanless, R.K., Stevens, R.D., Lachance, G.R., Delabio, R.N., 1970. K-Ar isotopic ages report 9; age determinations and geological studies. Geol. Surv. Can. Pap. 69-2, 1-78.

Wanless, R.K., Stevens, R.D., Lachance, G.R., Delabio, R.N., 1974. Isotopic ages report 12; age determinations and geological studies. Geol. Surv. Can. Pap. 74-2, 60-63.

Wanless, R.K., Bridgwater, D., Collerson, K.D., 1979a. Zircon age measurements for Uivak II gneisses from the Saglek area, Labrador. Can. J. Earth Sci. 16, 962-965.

Wanless, R.K., Stevens, R.D., Lachance, G.R., Delabio, R.N., 1979b. Age determinations and geological studies K-Ar isotopic ages report 14. Geol. Surv. Can. Pap. 79-2, 1-67.

Wardle, R.J., Gower, C.F., Ryan, B., Nunn, G.A., James, D.T., Kerr, A., 1997. Geologica Map of Labrador: 1:1 Million Scale. Government of Newfoundland and Labrador. Department of Mines and Energy, Geological Survey, Map 97-07.

Wasteneys, H.A., Wardle, R.J., Krogh, T.E., 1996. Extrapolation of tectonic boundaries across the Labrador shelf: U-Pb geochronology of well samples. Can. J. Earth Sci. 33, 1308-1324.

Wendt, J.I., Collerson, K.D., 1999. Early Archean U/Pb fractionation and timing of late Archean high-grade metamorphism in the Saglek-Hebron segment of the North Atlantic Craton. Precambrian Res. 93, 281-297.

Whitehouse, M.J., Kamber, B.S., 2005. Assigning dates to thin gneissic veins in high-grade metamorphic terranes: a cautionary tale from Akilia, Southwest Greenland. J. Petrol. 46 (2), 291-318.

Wiedenbeck, M., 1995. An example of reverse discordance during ion microprobe zircon dating - an artifact of enhanced ion yields from a radiogenic labile $\mathrm{Pb}$. Chem. Geol. 125 (3-4), 197-218.

Williams, M.L., Jercinovic, M.J., Harlov, D.E., Budzyń, B., Hetherington, C.J., 2011. Resetting monazite ages during fluid-related alteration. Chem. Geol. 283, 218-225.

Yi, K., Cho, M., 2009. SHRIMP geochronology and reaction texture of monazite from a retrogressive transitional layer, Hwachean granulite complex, Korea. Geochem. J. 13 (3), 293-304.

Zeck, H.P., Whitehouse, M.J., 1999. Hercynian, Pan-African, Proterozoic and Archean ion-microprobe zircon ages for a Betic-Rif core complex, Alpine belt, W Mediterranean - consequences for its P-T-t path. Contrib. Mineral. Petrol. 134 (2-3), 134-149. 